\title{
A new chronology for crannogs in north-east Scotland
}

\author{
Michael J Stratigos ${ }^{1}$ and Gordon Noble ${ }^{2}$
}

\begin{abstract}
This article presents the results of a programme of investigation which aimed to construct a more detailed understanding of the character and chronology of crannog occupation in north-east Scotland, targeting a series of sites across the region. The emerging pattern revealed through fieldwork in the region shows broad similarities to the existing corpus of data from crannogs in other parts of the country. Crannogs in north-east Scotland now show evidence for origins in the Iron Age. Further radiocarbon evidence has emerged from crannogs in the region revealing occupation during the 9th10 th centuries $A D$, a period for which there is little other settlement evidence in the area. Additionally, excavated contexts dated to the 11th-12th centuries and historic records suggest that the tradition of crannog dwelling continued into the later medieval period. Overall, the recent programme of fieldwork and dating provides a more robust foundation for further work in the region and can help address questions concerning the adoption of the practice of artificial island dwelling across Scotland through time.
\end{abstract}

\section{INTRODUCTION}

The presence of artificial island dwellings, or 'crannogs', in Scotland has been recognised since the 18th century, and were the target of antiquarian investigation from the mid-19th century (Stuart 1866; Munro 1882; Blundell 1909). North-east Scotland saw early work on crannogs (Burnett 1851; Grigor 1863; Stuart 1874), but since then there has been relatively little interest in crannogs of this region until recently (Stratigos \& Noble 2014; Stratigos 2016a, 2016b, 2017). Modern investigations of crannogs in Scotland have tended to focus on regions where there was a more robust and established track record of antiquarian research - like south-west Scotland (Barber \& Crone 1993; Henderson et al 2006; Cavers et al 2011) - or where there were more numerous extant submerged sites such as Loch Awe (McArdle et al 1973) and Loch Tay (Dixon 1981). Work in the second half of the 20th century and the early $21 \mathrm{st}$ century briefly noted the presence of crannogs in north-east Scotland, but no detailed studies existed (eg Morrison 1985: 2-4; Dixon 2004: 32 ), and at times they were regarded as solely a later, medieval and post-medieval phenomena in the region (eg Henderson 2009: 42; Cavers 2010: 26-8; Lenfert 2013: 133).

Recent work testing the distribution of crannogs across the country has shown that crannogs were more widespread in north-east Scotland than previously considered, with 33 possible sites now identified in the modern council areas of Aberdeenshire, Aberdeen City, Angus, Moray and Fife (a near three-fold increase on previous counts), though most have been impacted by drainage (Stratigos 2016a, 2016b, 2017: 49-83) (Illus 1). The new investigation of crannogs in north-east Scotland reported on here responded to calls for greater sampling of sites to build chronologies with the aim of constructing frameworks that assess the adoption and use of crannogs across Scotland (Dixon 2004: 176-7; Dixon et al 2007: 683; Crone 2012: 164-5), but with this greater presence of crannogs in the study area in mind. The present work also set out to test the classifications and chronology of crannogs in

\footnotetext{
${ }^{1}$ Scottish Universities Environmental Research Centre, Scottish Enterprise Technology Park, Rankine Avenue,

East Kilbride G75 0QF. All images prepared and (c) Michael J Stratigos

${ }^{2}$ University of Aberdeen, School of Geosciences, St Mary's, Elphinstone Road, Aberdeen AB24 3UF
} 


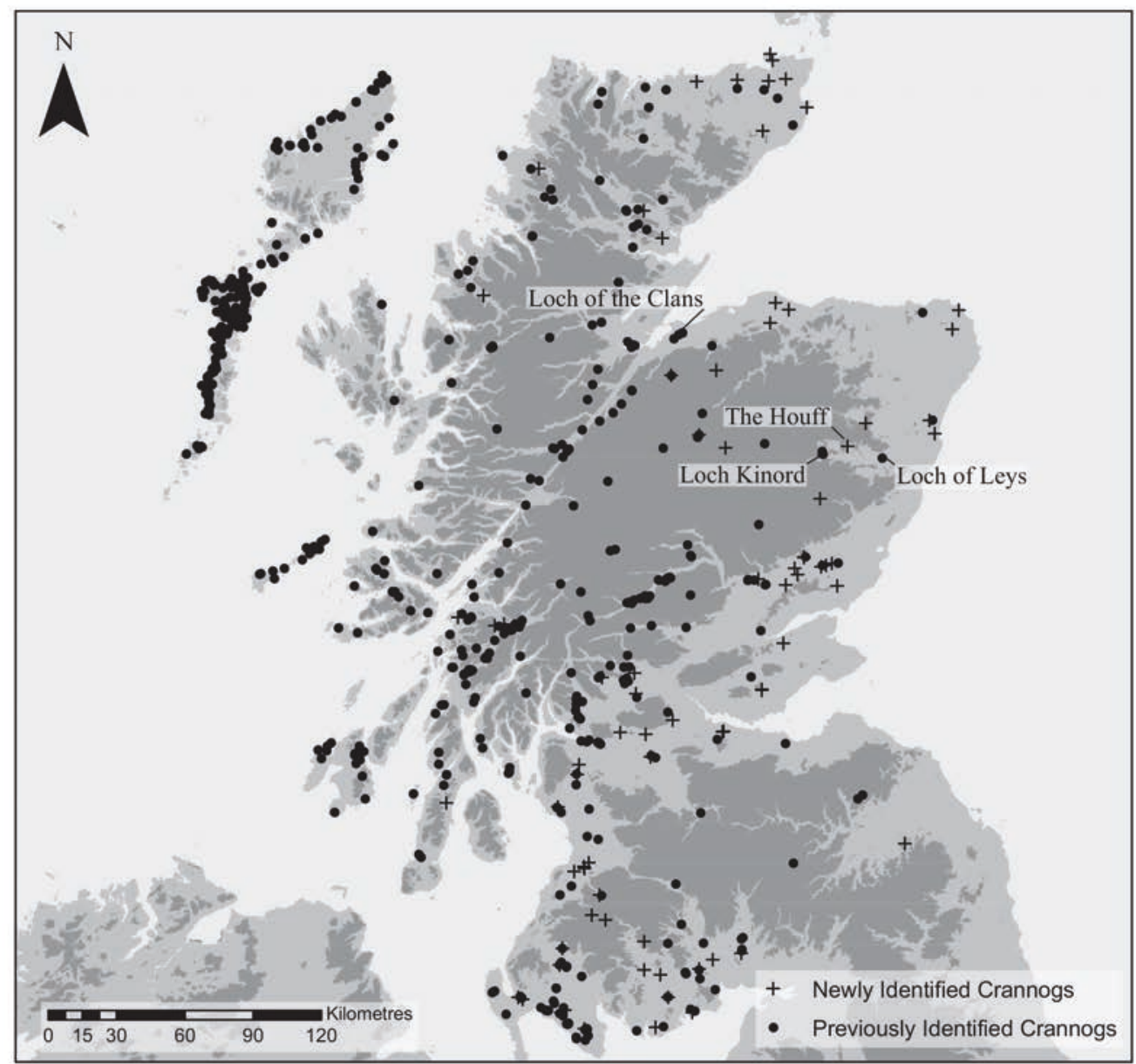

ILLUS 1 Location map showing sites investigated as part of this programme of work. The map shows previously identified crannogs collated in Cavers (2010) and Lenfert (2012), and newly identified crannogs from Stratigos (2017)

an under-explored region (cf Henderson 1998; Harding 2000). Recent work examining islet duns in western Scotland has called into question some of the traditional typological distinctions applied to crannogs and islet duns, viewing them as cognates to the mainland crannog building tradition (Cavers 2010: 34; Lenfert 2013). This dramatically increases the number of crannog sites in western Scotland (Illus 1), and has had the effect of furthering the perception that crannogs are a typically western or Atlantic Scottish tradition, especially in an Iron Age context (Henderson 2009). Developing highresolution chronologies using dendrochronology and wiggle-match dating for crannogs has also been piloted in south-west Scotland where the most intensively excavated crannogs are found (Crone 2014; Jacobsson 2015; Jacobsson et al 2017). These studies improve our understanding of crannogs with finer resolution of the timings and tempo of crannog use, but questions remain outwith a few well-researched regions. Notably, this includes whether the crannog tradition in eastern Scotland was solely a later phenomenon 
or also emerged in the Iron Age, like the western half of the country.

The two radiocarbon dates obtained from an early phase of the recent work on crannogs in north-east Scotland returned 9th-10th century AD dates (Stratigos \& Noble 2014). Given that the bulk of radiocarbon evidence from crannogs fall in the period $800 \mathrm{BC}-\mathrm{AD} 400$ (Crone 2012), these dates gave some credence to north-east crannog building being a relatively late phenomenon (see Henderson 2009; Cavers 2010: 26). Nonetheless, initial results from Loch Kinord provided dates for a period in which crannog settlement - and settlement more generally - is poorly attested. Further work was seen as highly likely to add to our understanding of the nature of crannogs, in particular their chronology, in a poorly researched region. In this context, the present research was conducted to build a chronological framework and to test some basic questions about the adoption of the artificial island dwelling tradition in the region.

\section{AIMS AND METHODS}

From 2014 to 2017, a programme of work was undertaken to build a more extensive dataset for crannogs and their dating in north-east Scotland. North-east Scotland is considered here as the modern council areas of Aberdeenshire, Aberdeen City, Angus, Moray and Fife (cf Stratigos \& Noble 2014; Stratigos 2016b), but also included one site (Loch of the Clans) from historic Nairnshire (now within Highland Council). Targets within the region of interest were selected based on capturing a range of preservation conditions and accessibility for survey and excavation. Initial work focused on producing desk-based assessments for each target site and modelling the former extents of lochs around potential and known sites using available survey and historical data. Topographic surveys were made over each site, extending below water at the submerged sites at Prison and Castle Islands, Loch Kinord. These surveys were completed using a dGPS alongside tapes where needed. Trenches were opened using standard archaeological methods and samples were retrieved for dating.

\section{CRANNOGS INVESTIGATED}

THE HOUFF (NJ50SE 4), LOCH AUCHLOSSAN, ABERDEENSHIRE

The Houff, located near Lumphanan, Aberdeenshire, is recorded as a 'fort' or 'possible motte' in the Canmore database and as an 'earthwork' and 'medieval ringwork' in the Aberdeenshire SMR. The primary aim of the work carried out here was to test the potential reidentification of the site as a crannog. The site is located in an arable field and stands as a grass-covered mound about $3 \mathrm{~m}$ high, measuring $45 \mathrm{~m} \times 32 \mathrm{~m}$ (Illus 2). There is stone-work visible around the entirety of the mound with more substantial walling, standing to over five courses high, located on the top of the mound. This masonry probably relates to the use of the Houff as a burial ground in the 16th and 17th centuries, (NSA vol 12: 1091). The southern half of the mound has been severely disturbed by quarrying activity in the 1960s, when three partial skeletons and remains of a coffin were found. The site was included in an inventory of north-east Scotland's mottes and castles (Yeoman 1988: 130), but no intrusive archaeological investigation had been previously carried out.

Initial scoping work showed that the Houff was likely to have been within the former Loch Auchlossan. Loch Auchlossan is described in the New Statistical Account of Scotland as extending over 600 acres (242ha) and reaching as far as the foot of the Peel of Lumphanan (NSA vol 12: 1050). The loch was first partly drained in the late 17 th century, but complete drainage was only achieved after deep ditches, tunnels and 'other means', were employed in 1860 (Groome 1884: 85). There are no detailed maps of this area from before 1700 , but the Roy Military Survey of Scotland (1747-55) depicts the loch, albeit in reduced form (Sheet C.9.b 20/1a) (Roy 2007). Importantly, the recorded archaeology that pre-dates 1700 in this area respects a shoreline consistent with the description that the former loch extended (nearly) to the foot of the Peel of Lumphanan (Stratigos 2016a: 44-5). Two recorded features are particularly notable here. The first is a trackway (NJ50SE 21) which was excavated in 1989 ahead of drainage works. 
The trackway was interpreted as being at the margins of the former Loch Auchlossan and sits at $c 145 \mathrm{~m}$ OD (Sutherland 1989). The second is the nearby Auchenhove Castle (NJ50SE 1), built by the Duguid family in the late 16th century, and destroyed in 1745 . The castle would have sat on a natural island in the loch, and Simpson (1929: 23) suggests it was approached by a causeway. Although he makes no specific mention of the former extent of Loch Auchlossan, this would accord with the proposed shoreline at $145 \mathrm{~m}$ OD (Illus 2). The only recorded archaeological sites likely dating to before 1700 from within the area described by the $145 \mathrm{~m}$ OD contour are a logboat (NJ50SE 9) (Mowat 1996: 26) and the Houff.

Topographic survey showed the Houff sits on an oval-shaped rise, of apparently natural origin, within a field at $c 142 \mathrm{~m}$ OD. This sits approximately $3 \mathrm{~m}$ below the proposed palaeoshoreline of $145 \mathrm{~m}$ OD. The mound itself rises $3.5 \mathrm{~m}$ above the oval-shaped rise, placing the very top of the Houff just above the former waterline. This depth and overall morphology is consistent with other crannogs (see Henderson 1998; Cavers \& Henderson 2005; Shelley 2009: appendix A; Cavers et al 2011). The topographic survey also showed how the southern portion of the mound has been levelled and disturbed by the 1960 s quarrying activity (Illus 2c).

During August 2015 a $2.8 \mathrm{~m} \times 1 \mathrm{~m}$ trench was opened in the lower reaches of the mound on its north side. A very simple

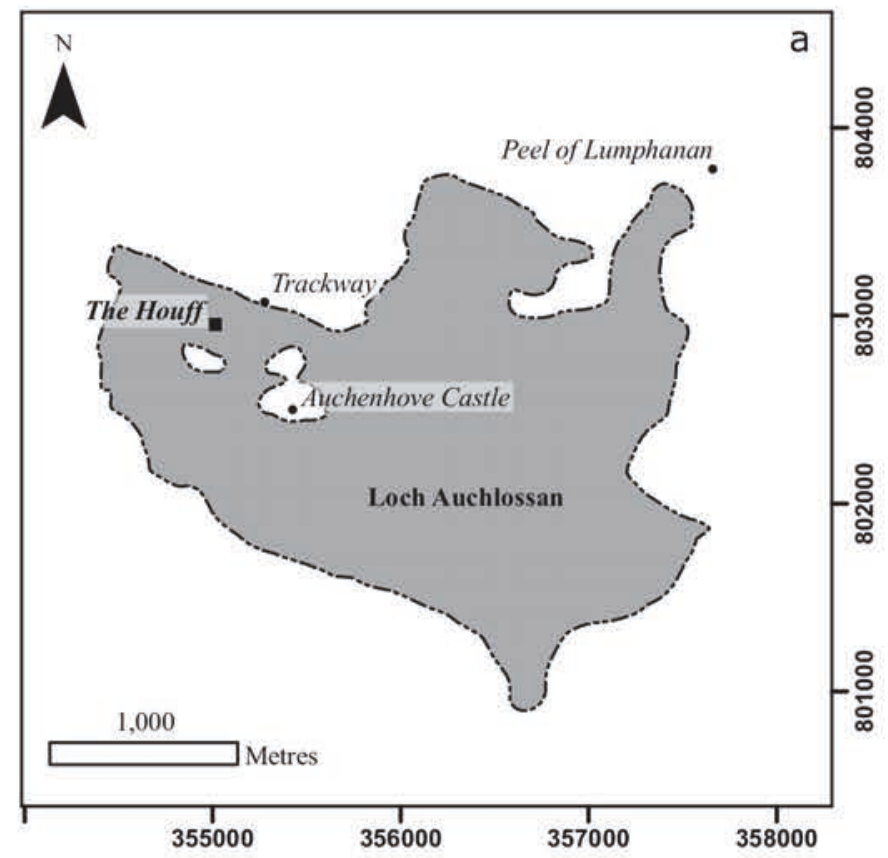

ILlus 2 (a) Location of the Houff in relation to the former Loch Auchlossan and other notable recorded archaeological features; (b) the Houff looking north

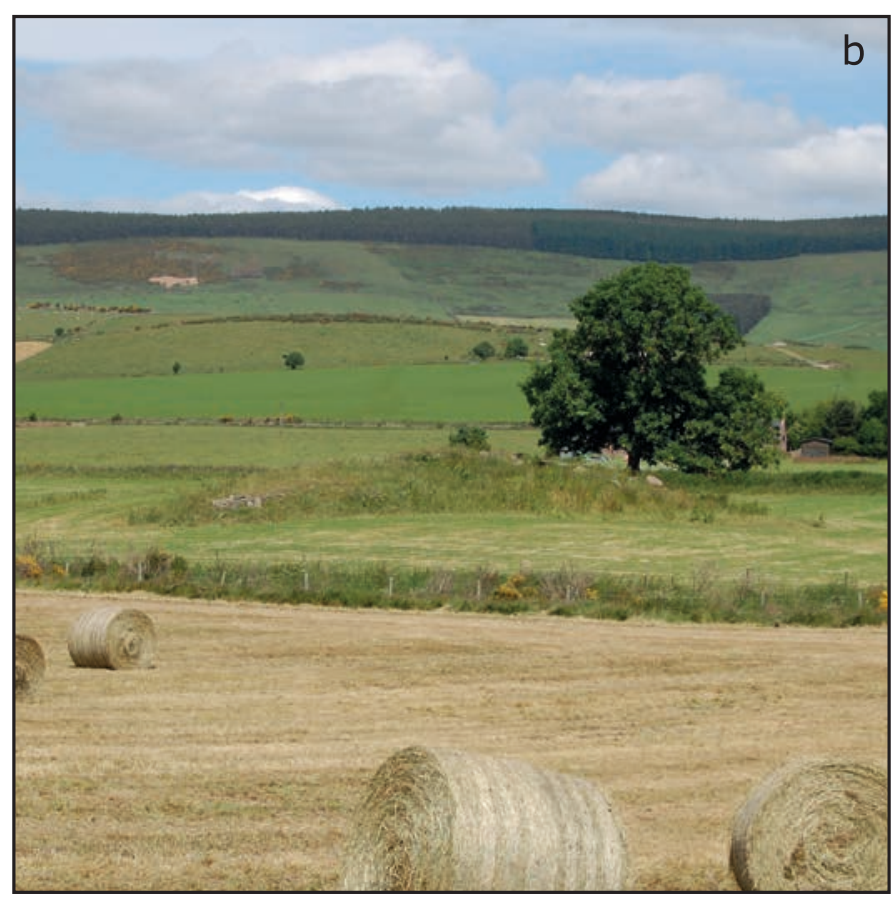




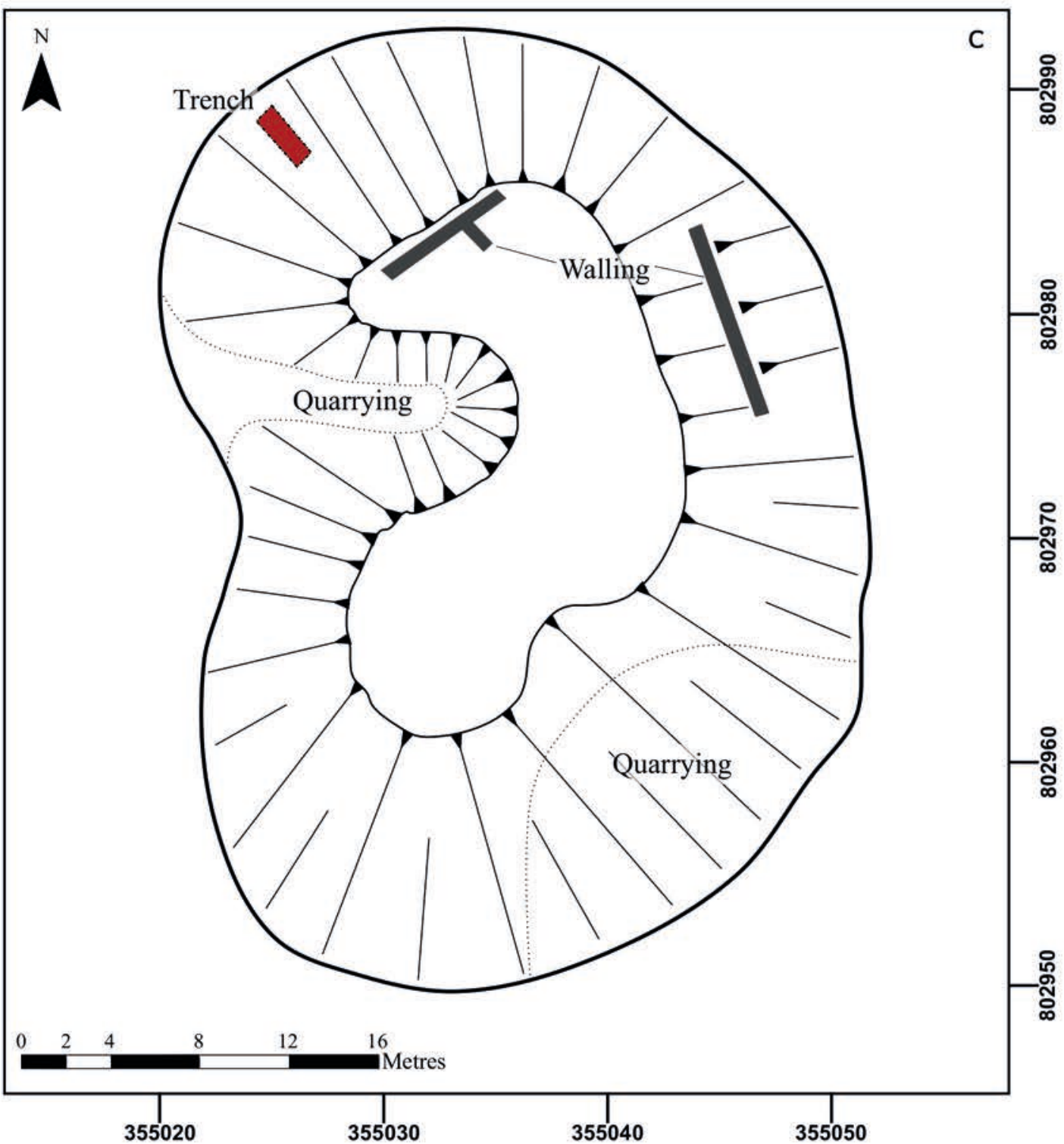

ILLus 2 (c) Survey of the Houff and location of the excavation trench

profile was recorded in the trench with topsoil (HF15_101) overlying a dark, organic rich sediment with charcoal and carbonised wood (HF15_102) alongside a very sandy sediment with charcoal inclusions, carbonised wood and a single fragment of bone (HF15_103) (not in section). Below (HF15_102) and (HF15_103) was a sterile gravelly sand (HF15_104), interpreted as a glacio-fluvial or lacustrine sediment, upon which the Houff sits (Illus 3). This sediment sequence and its location almost certainly within the former extent of Loch Auchlossan is strong evidence that the Houff was originally built as a crannog.

A single entity roundwood charcoal sample from the lowest third of (HF15_102) nearest the 


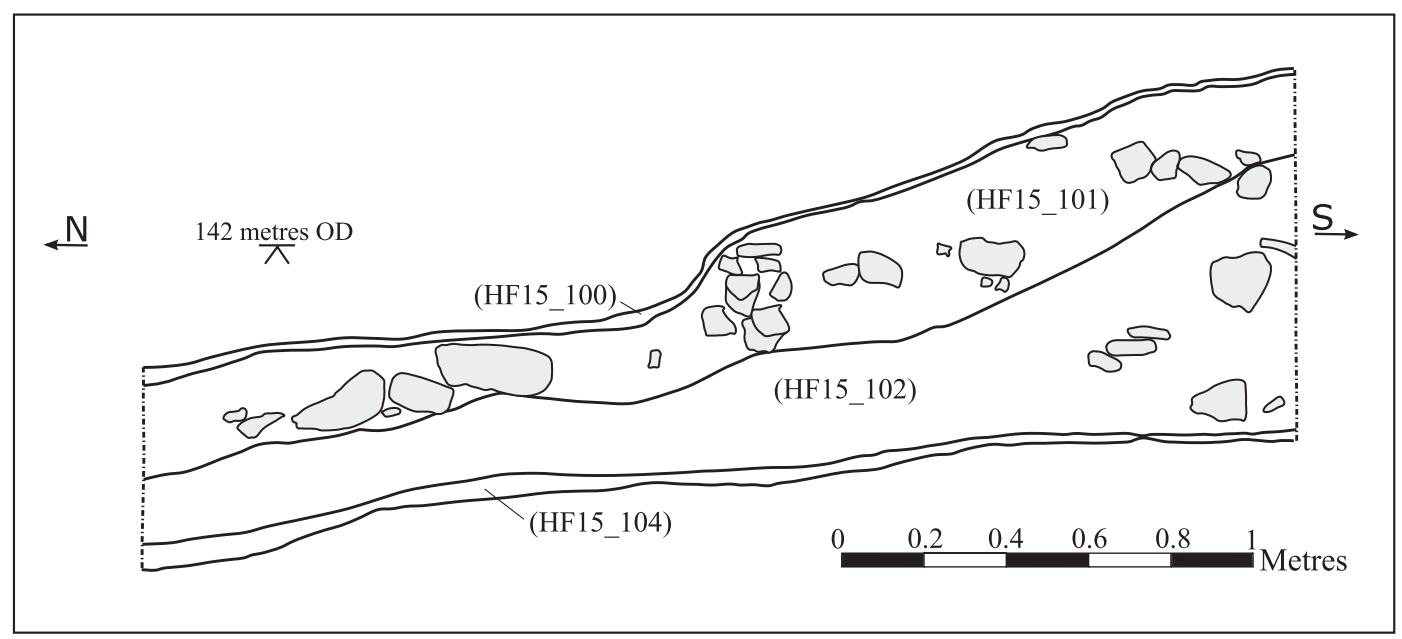

ILLus 3 West-facing section of excavation trench at the Houff

centre of the mound was selected for ${ }^{14} \mathrm{C}$ dating. The bulk sample contained almost exclusively alder charcoal and charred wood. This is notable since alder is the most common wood encountered on crannog sites (see Crone 2014). The sample returned a radiocarbon date of cal AD 1490-1650 (95.4\% probability, Poz-77625) (Table 1).

\section{LOCH OF THE CLANS I CRANNOG (NH85SW 1), LOCH OF THE CLANS, NAIRNSHIRE}

There are two recorded crannogs in the Loch of the Clans, only one of which survives as a visible monument - the site targeted by excavation here, Loch of the Clans I (Illus 4a). The former loch is now a bog with areas of reclaimed arable and grazing land surrounding it. Loch of the Clans I sits at the margin of the bog, in a field sloping to the south (towards the centre of the loch). The mound measures $20 \mathrm{~m}$ in diameter and stands proud of the surrounding field by $1-1.5 \mathrm{~m}$ (Illus $4 \mathrm{~b}, 4 \mathrm{c})$. The centre of the crannog mound has been hollowed out, likely from antiquarian excavation (Grigor 1863, 1864). The antiquarian trench has since been mostly infilled by modern waste.

Following drainage in 1823 , the New Statistical Account records the discovery of a logboat found between Loch of the Clans I and the former north shore of the loch. The account mentions the presence of the two crannogs, that the logboat was cut up and destroyed, and that a 'bolt of a lock of no ordinary size' was taken from the site (NSA vol 14: 448). The two crannogs in the loch were first reported in antiquarian literature by Dr John Grigor who carried out excavation on both. He was alerted to the extant crannog when the tenant farmer ploughed through the lower section of the mound 20 years after the drainage of the loch (Grigor 1863). Excavation through the mound in 1862 revealed well-preserved layers of horizontal timbers and occasional vertical piling. The only artefacts recovered from the excavation included a clay or stone cup and some stone tools. Grigor (1864) records sloping timbers that he suggested may have been related to rafters for a roof. Based on the excavation sketches, these 'rafters' may be cautiously reinterpreted as horizontal timbers, of the kind that frequently make up the foundations of packwerk crannog mounds (see Crone \& Campbell 2005; Cavers 2007: 243) (although roof purlins were identified at Milton Loch crannog (Piggot 1953: 139-43)). Grigor (1864: 333) also described what he viewed as a roughly rectangular structure which has parallels at a range of crannog sites (see Munro 1893; Ritchie 1942; Crone 2007: 225). Grigor also made cursory examination of the 


\begin{tabular}{|c|c|c|c|c|c|c|c|c|c|c|c|c|c|c|}
\hline & $\underset{\infty}{0}$ & 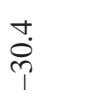 & ڤે̀े & $\overrightarrow{\grave{i}}$ & $\underset{\sim}{\stackrel{\nabla}{~}}$ & ڤे & 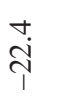 & $\stackrel{i}{i}$ & $\begin{array}{l}\stackrel{+}{*} \\
\stackrel{\sim}{i}\end{array}$ & ণัे & ڤે̀े & $\vec{\oplus}$ & $\vec{\sim}$ & ֶָ. \\
\hline & 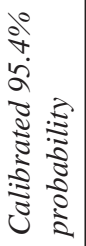 & 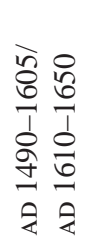 & $\begin{array}{l}\stackrel{0}{n} \\
\stackrel{1}{1} \\
n \\
e\end{array}$ & 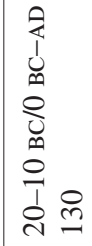 & $\begin{array}{l}0 \\
0 \\
\frac{1}{1} \\
8 \\
\infty \\
\infty \\
\&\end{array}$ & 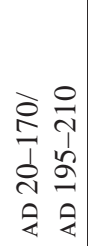 & $\begin{array}{l}0 \\
\infty \\
n \\
2 \\
n \\
1 \\
\infty \\
\infty\end{array}$ & $\begin{array}{l}2 \\
0 \\
1 \\
1 \\
\infty \\
n \\
2 \\
\&\end{array}$ & $\begin{array}{l}n \\
0 \\
1 \\
0 \\
\infty \\
\infty \\
2 \\
\&\end{array}$ & 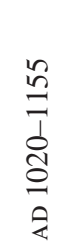 & $\begin{array}{l}n \\
= \\
= \\
0 \\
0 \\
0 \\
8\end{array}$ & 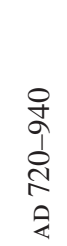 & 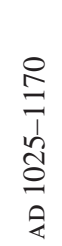 & 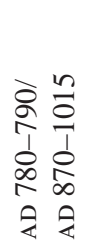 \\
\hline & 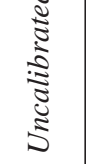 & $\begin{array}{l}0 \\
\oplus+1 \\
+1 \\
\stackrel{n}{n} \\
e\end{array}$ & $\begin{array}{l}0 \\
\infty \\
+1 \\
\stackrel{1}{\infty} \\
\curvearrowright\end{array}$ & \begin{tabular}{l} 
O \\
+1 \\
+1 \\
\multirow{2}{*}{} \\
\multirow{2}{*}{}
\end{tabular} & 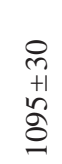 & $\begin{array}{l}\stackrel{0}{\oplus} \\
+1 \\
0 \\
\stackrel{2}{2}\end{array}$ & $\begin{array}{l}0 \\
m \\
+1 \\
0 \\
b \\
n\end{array}$ & 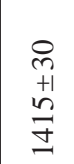 & $\begin{array}{l}\stackrel{0}{\oplus} \\
+1 \\
0 \\
\Xi\end{array}$ & $\begin{array}{l}0 \\
\cdots \\
+1 \\
n \\
n\end{array}$ & $\begin{array}{l}\text { O } \\
\text { +1 } \\
\text { Oे } \\
\text { ă }\end{array}$ & $\begin{array}{l}\stackrel{0}{m} \\
+1 \\
\stackrel{1}{a} \\
\triangleq\end{array}$ & $\begin{array}{l}\text { ô } \\
+1 \\
\\
\alpha\end{array}$ & $\begin{array}{l}\stackrel{P}{\infty} \\
+1 \\
\stackrel{n}{0} \\
\equiv\end{array}$ \\
\hline $\begin{array}{l}\breve{y} \\
\vdots \\
\vdots \\
.0\end{array}$ & 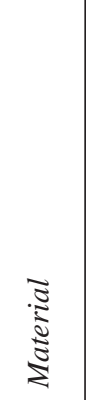 & 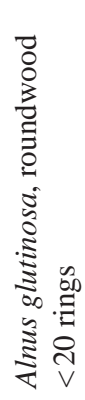 & 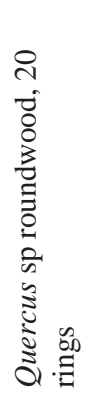 & 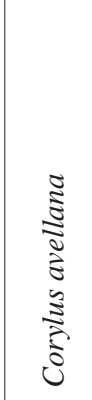 & 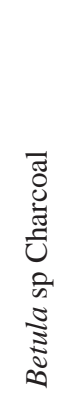 & 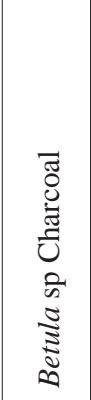 & 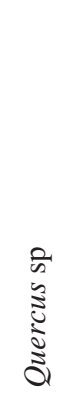 & 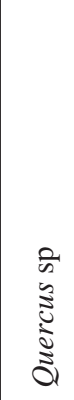 & 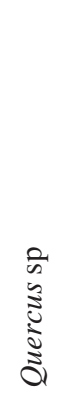 & 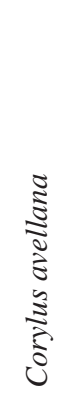 & 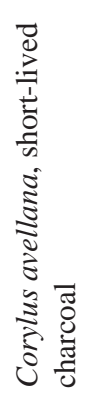 & $\begin{array}{l}0 \\
0 \\
5 \\
0 \\
0 \\
0 \\
0 \\
0\end{array}$ & 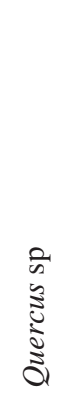 & 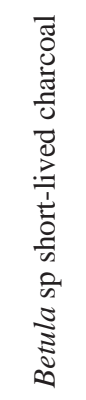 \\
\hline 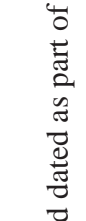 & 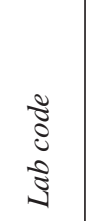 & 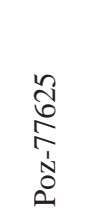 & 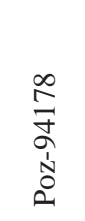 & 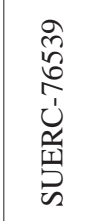 & 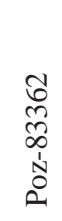 & 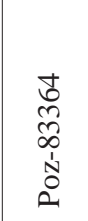 & 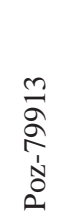 & 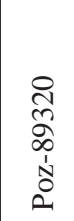 & 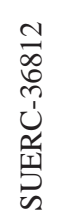 & 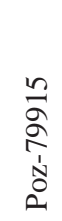 & 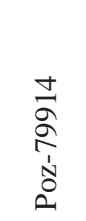 & 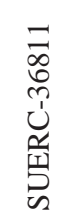 & 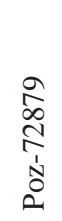 & 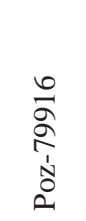 \\
\hline 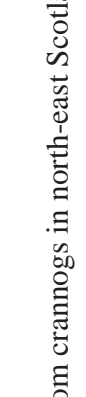 & ن & 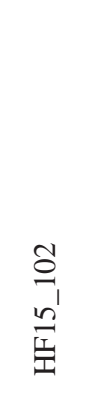 & 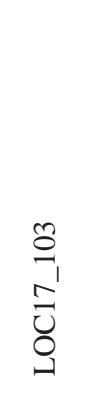 & 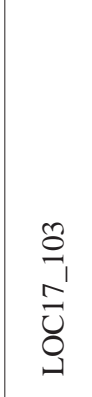 & $\begin{array}{l}0 \\
0 \\
0 \\
0 \\
\cdots \\
0 \\
0\end{array}$ & $\begin{array}{l}\infty \\
0 \\
\vdots \\
0 \\
0 \\
0 \\
0 \\
\end{array}$ & 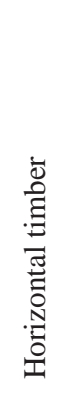 & 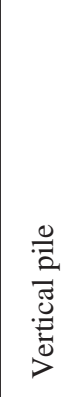 & 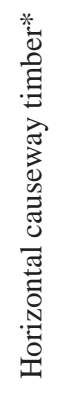 & $\begin{array}{l}\exists \\
\nabla_{1} \\
n^{\prime} \\
\exists\end{array}$ & 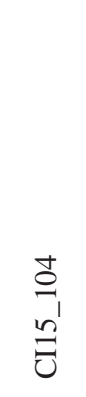 & 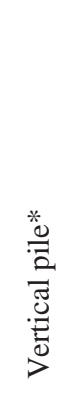 & 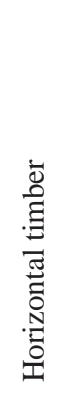 & 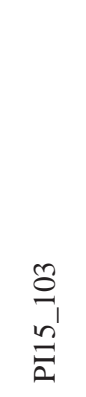 \\
\hline 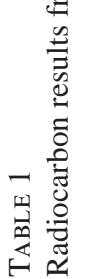 & $\ddot{\hbar}$ & 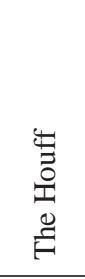 & & 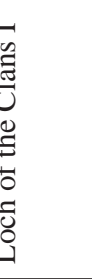 & & 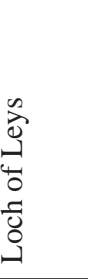 & & & 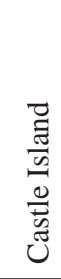 & & & & 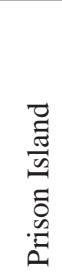 & \\
\hline
\end{tabular}


second crannog, which does not stand proud of the bog today. He notes here that the site was formed of a group of upright oak piles and some stones. Grigor (1864) lamented that only minimal work could be undertaken due to waterlogging. No trace of this second crannog was identified in the present survey.

The description of the former loch suggests a relatively narrow loch, about one mile in length (OSA vol 11: 562). This description accords well with the OS $5 \mathrm{~m} \times 5 \mathrm{~m}$ digital terrain model which shows a very well-defined basin with a probable shoreline at a maximum of $33.5 \mathrm{~m}$ OD. This would make the loch $1.67 \mathrm{~km}$ long and a maximum of $200 \mathrm{~m}$ wide (Illus $4 \mathrm{a}$ ). A palaeoshoreline at $33.5 \mathrm{~m}$ OD places Loch of the Clans crannog about $30 \mathrm{~m}$ into the loch from the nearest shore. The base of the crannog would have been in $c 3 \mathrm{~m}$ of water. The top of the site as it stands now is at $32 \mathrm{~m} \mathrm{OD}$, and its base on the south side sits at $30.5 \mathrm{~m}$ OD. The site would have been completely submerged with the former shoreline at $33.5 \mathrm{~m}$ OD. This fits comfortably within the range of depths in which we find crannogs in extant lochs (eg Oakbank crannog, Dixon 2004: 127). The topographic survey of the site also determined the extent of Grigor's (1864) intervention which essentially hollowed out the centre of the crannog mound (ibid: plate 22) (Illus 4c).

An evaluation trench was positioned on the south side of the crannog mound. The trench was placed here to miss areas impacted by Grigor's excavations, to avoid the modern rubbish deposited in the interior of the site, and to take in a lower section of crannog mound where it was more likely to contain waterlogged deposits. The $2 \mathrm{~m} \times 2 \mathrm{~m}$ trench contained three distinct layers, like at the Houff - topsoil (LOC17_101), the anthropogenic mound (LOC17_102), (LOC17_103), (LOC17_104) and natural lake sediment (LOC17_105) (Illus 5). Two single entity short-lived charred wood samples from the crannog mound were sent for radiocarbon dating. The lower sample was a charred wood fragment (Quercus sp) of no more than 20 years of growth, located at the interface between the 


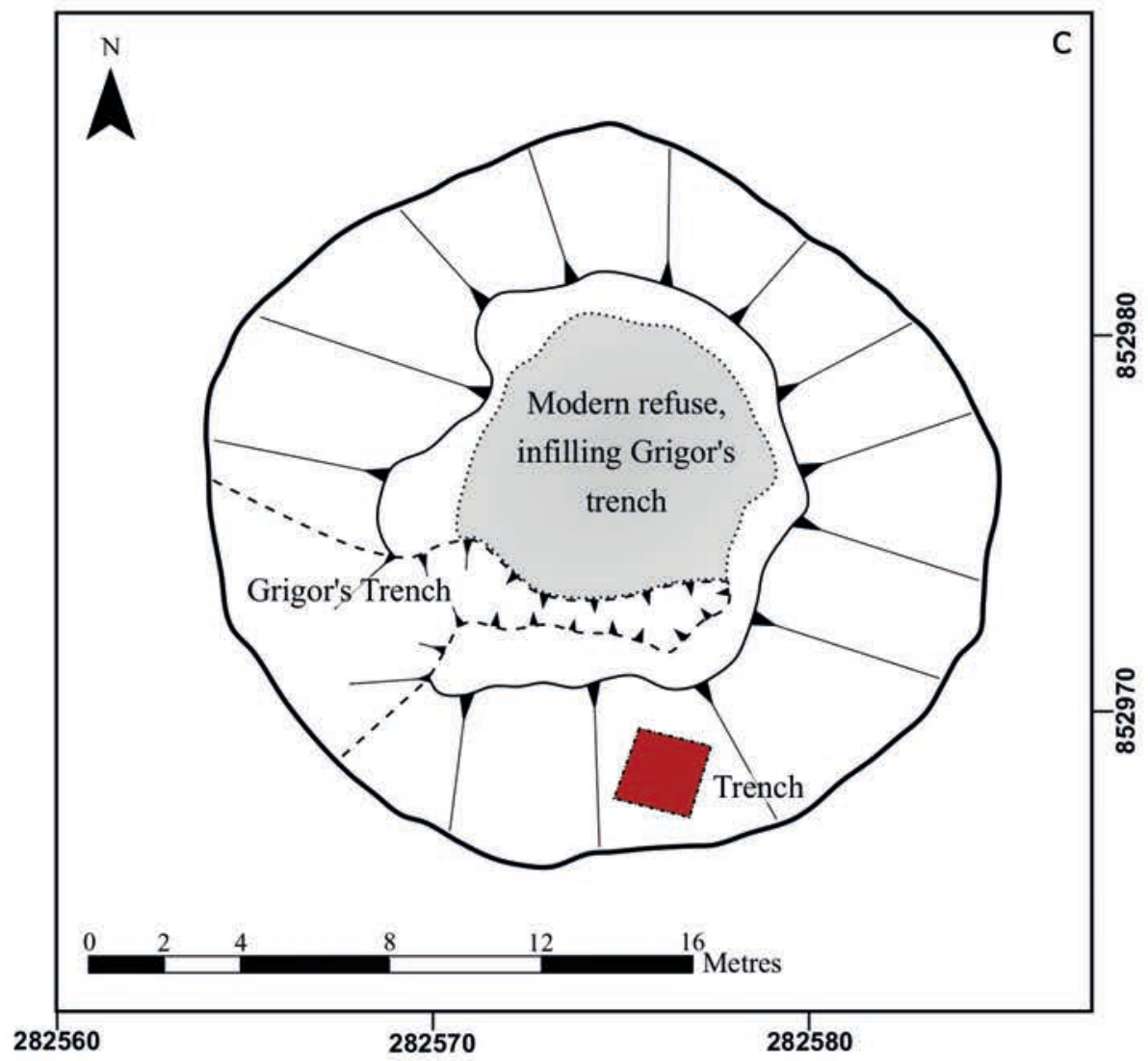

ILLus 4 (c) Survey of the Loch of the Clans I and location of the excavation trench

crannog (LOC17_103) and the lake sediment (LOC17_105). The sample returned a date of cal AD 5-130 (95.4\% probability, Poz-94178). The second sample (removed from a Kubiena tin sample) came higher in the profile and returned a similar date of cal AD 55-225 (95.4\% probability, SUERC-75950) (Table 1). This might suggest that use of the site was constrained to a relatively short span of time, possibly a single phase.

\section{LOCH OF LEYS CRANNOG (NO79NW 3), BANCHORY, ABERDEENSHIRE}

The Loch of Leys crannog is located in the drained Loch of Leys, now a bog, at 71m OD about $2 \mathrm{~km}$ north of the town of Banchory. The site is roughly oval measuring $43 \mathrm{~m} \times 20 \mathrm{~m}$ (Illus $6)$. The bog around the crannog is exceptionally wet and, in all but the driest of summers, renders the site effectively inaccessible. There are upstanding stone walls from a historically attested medieval tower house or castle surviving on the island (Burnett 1851).

The Loch of Leys crannog was the home of the Burnett of Leys family prior to moving to Crathes Castle. In the 14th century, the Loch of Leys crannog appeared in a charter dated 28 March 1323, where Robert the Bruce granted to Alexander Burnard (the family name latterly became Burnett) the 'isle of the Loch of Banchory' and its attendant estate. The reason, expressly stated in the charter, was to reward Alexander Burnard for supporting Bruce's campaigns during the Wars of Independence in the first half of the 14th century (Bailey 2000: 225-6). 


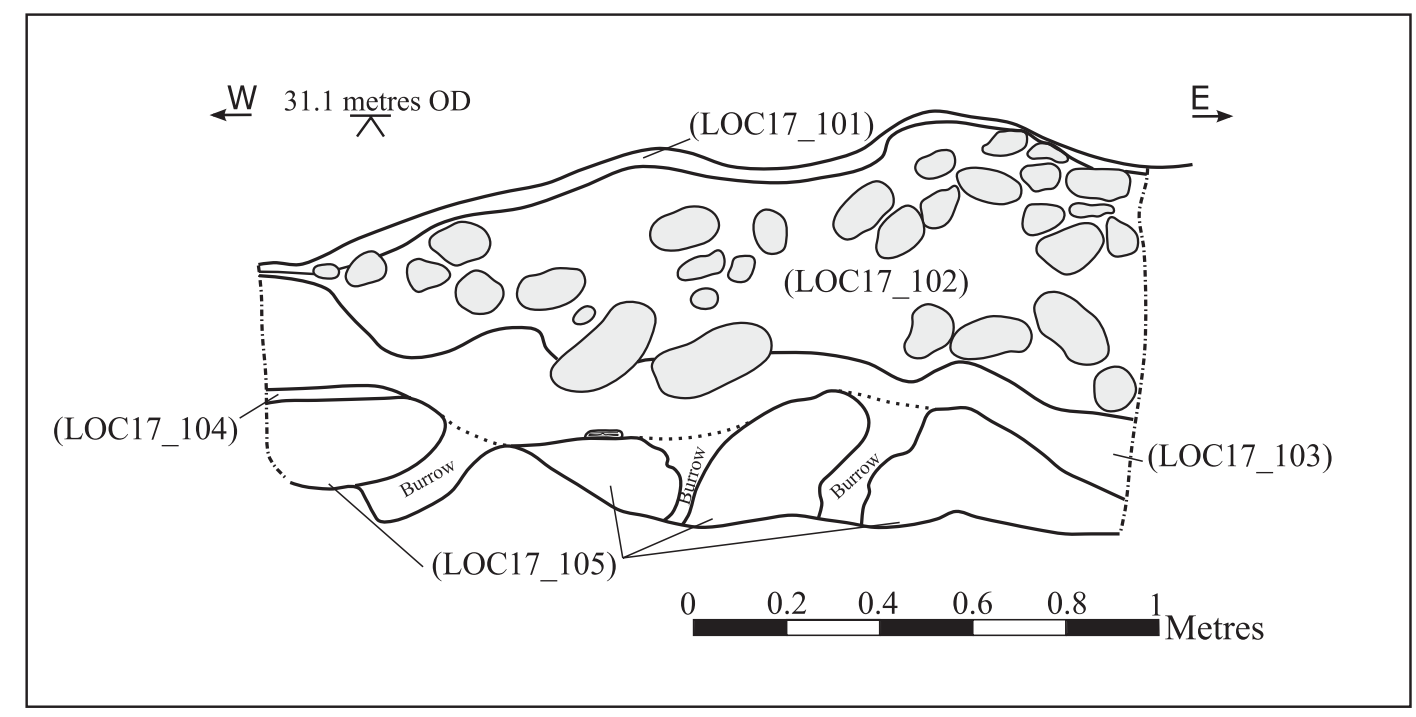

ILLUS 5 South-facing section of excavation trench at the Loch of the Clans I

The Loch of Leys crannog was excavated by James $\mathrm{H}$ Burnett in 1850, immediately following drainage of the loch (Burnett 1851). Burnett records a timber foundation of oak and birch layers perpendicular to each other. This was surrounded by vertical oak piles. Coins and a quernstone were noted as coming from the crannog, while a number of bronze artefacts were also found, apparently associated with one of two logboats found in the loch when it was drained (Mowat 1996: 68, 111, 121). Three of the bronze vessels are now within the National Museum of Scotland (Accession numbers: H.MA 6; H.MA 7; H.MGI 111), and four others are at Crathes Castle in the care of the National Trust for Scotland (Accession numbers: 51.640; 51.641 ; 51.642; a large bronze cauldron is unnumbered, but appears to be the vessel illustrated in Munro (1882: 24)). All the bronze artefacts are medieval, probably dating between the 14th and 16th centuries. There is no record of where Burnett dug on the crannog, but his spoil heaps appear to be within the outline of the later castle foundations.

The New Statistical Account suggests that an attempt to drain the loch was made as early as the 1730s (vol 11: 328). This is supported by its depiction on the Roy Military Survey of Scotland (1747-55) which shows the loch, giving the impression of boggy ground around the partially drained loch, and a very straight outlet burn which matches the course of the Bennie Burn that currently drains the loch basin, suggesting it had been cut by the time of the survey (Sheet C.9.b 20/1e) (Roy 2007). The palaeoshoreline of the Loch of Leys can be proposed to have been at $75 \mathrm{~m}$ OD based on the depiction of Roy, historical descriptions and allowing for earlier drainage attempts (Illus 6a).

The topographic survey showed that the crannog mound rises $2.5 \mathrm{~m}$ above the surface of the surrounding bog at $73.5 \mathrm{~m}$ OD - below the proposed former shoreline at $75 \mathrm{~m}$ OD. However, the top of this crannog necessarily sat above the water at some point, given the medieval foundations of the castle. There are two possible explanations here; the proposed former shoreline is too high by $2-3 \mathrm{~m}$ or the crannog mound has substantially subsided. We favour the latter interpretation here, as there is reasonable confidence in the historic mapping for a shoreline at $75 \mathrm{~m} \mathrm{OD}$, and the excavated contexts also point to likely subsidence following drainage (see below). The surviving walling on 
top of the mound survives to a maximum height of $0.7 \mathrm{~m}$. With the exception of the western walls, the structure survives as Burnett recorded it in 1850. An entrance is apparent on the south side of the island, consistent with Burnett's plan of the site (Illus 6c).

A single $2 \mathrm{~m} \times 3 \mathrm{~m}$ trench was opened on the west side of the crannog mound in February 2016, about a metre from where the bog meets the crannog mound (Illus 6c). Again, a welldrained site was identified with topsoil (LOL16_101) above an undifferentiated anthropogenic mass (LOL16_103) sitting on natural lacustrine deposits (LOL16_105) (Illus 7). Additional contexts were identified above the main organic crannog mound, which included well-laid stonework, cutting into and capping the mound [LOL16_106] (not in section). Above this stone was what was first thought to be in situ accumulation of material relating to use of the site following construction of the stone capping. This included (LOL16_108) which was sampled for ${ }^{14} \mathrm{C}$ dating, but the radiocarbon result required reinterpretation of

this (see below). The excavation showed that the Loch of Leys crannog is better preserved than the Houff or Loch of the Clans I, but the same pattern of mineralisation of the organic mass of the crannog is evident. This decay of the mostly organic foundations of the crannog, alongside the sediment compression following drainage

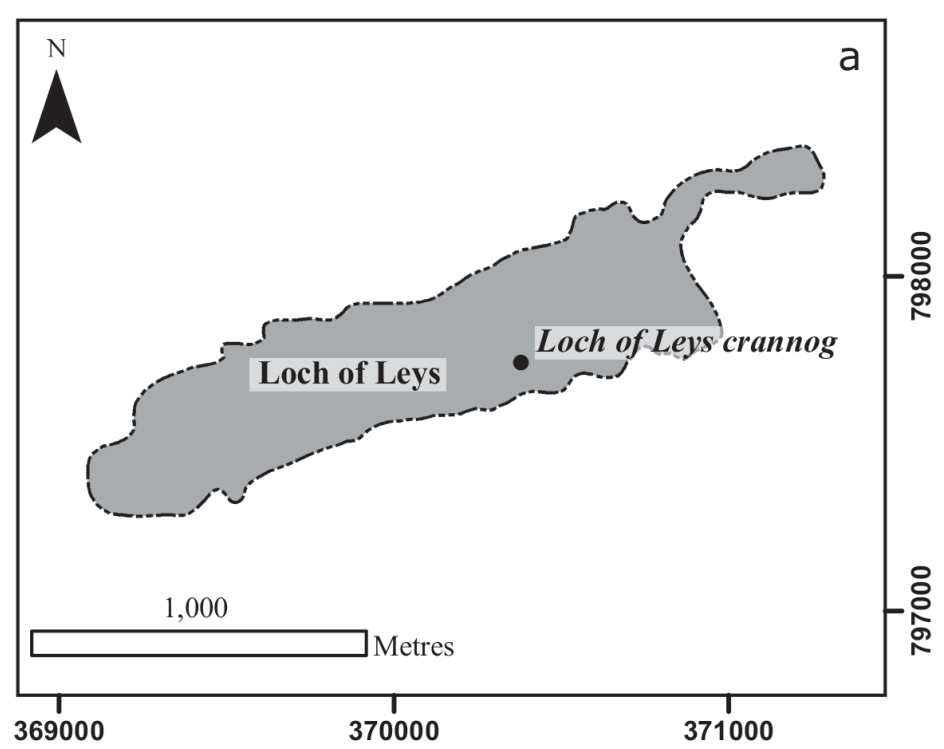

ILLUS 6 (a) Location of the Loch of Leys crannog in relation to the former extent of the loch; (b) the Loch of Leys crannog looking north, the extent of the mound is indicated by the taller trees on the island

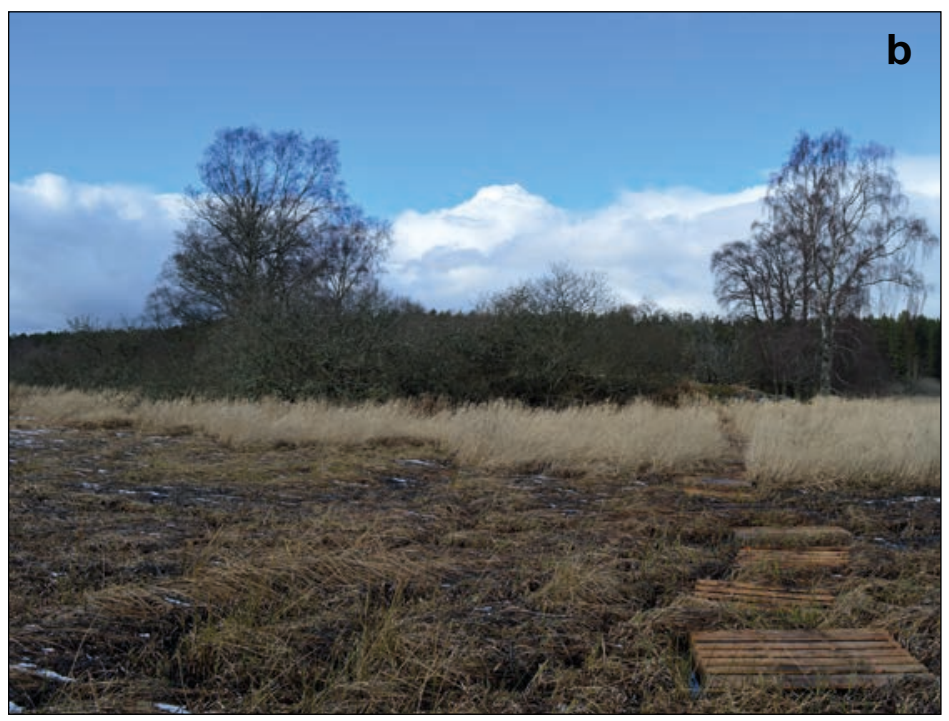

is most likely responsible for the apparent discrepancy between the current height of the mound at $73.5 \mathrm{~m}$ OD and the height of the former shoreline at $75 \mathrm{~m}$ OD.

Two samples were submitted for ${ }^{14} \mathrm{C}$ dating from different stratigraphic levels. A charcoal sample from (LOL16_103) returned a date 


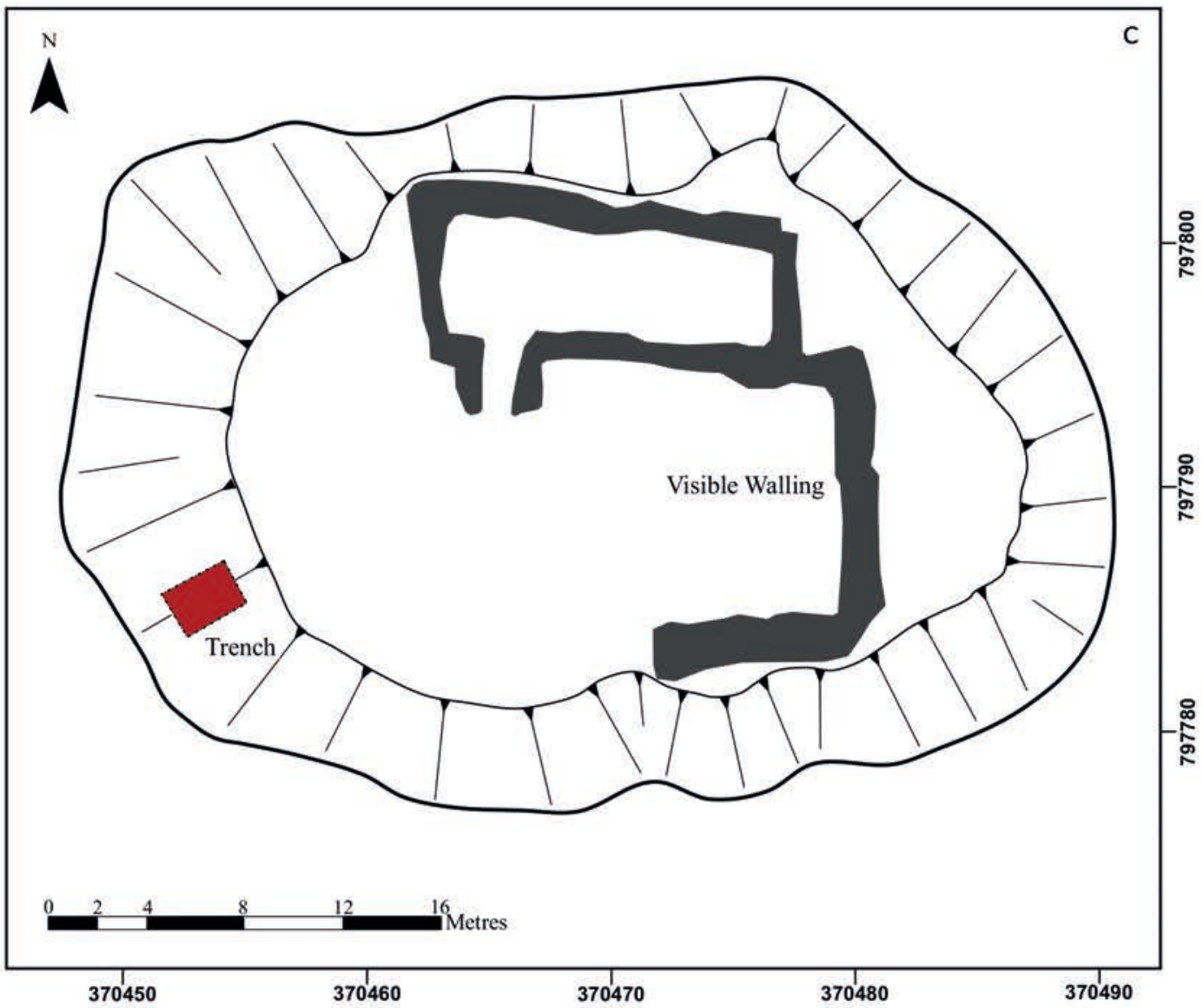

ILLUS 6 (c) Survey of the Loch of Leys crannog and location of the excavation trench

of cal AD 890-1015 (95.4\% probability, Poz83362), while another charcoal sample from (LOL16_108) returned a date of cal AD 20-210 (95.4\% probability, Poz-83364) (Table 1). This represents an inversion in the stratigraphy (Illus 7). It was thought (LOL16_108) would represent later activity at the site laid down during its use as a tower house, but it seems clear now that (LOL16_108) represents a secondary context composed of redeposited material. While the security of this context is questionable, the date is likely to represent a phase of construction or use at the crannog, since the crannog itself is the most likely source for charred material dating to the Roman Iron Age in contexts above those dating probably to the 10th century AD.
CASTLE ISLAND, LOCH KINORD, ABERDEENSHIRE

Loch Kinord is located in Upper Deeside, where two crannogs are complemented by a terrestrial archaeological landscape that includes a group of roundhouses, souterrains, field systems, a promontory fort, an elaborately carved stone cross-slab and a medieval moated site (Illus 8). In addition to the extant archaeological monuments around Loch Kinord, a range of artefacts were recovered from within and around Loch Kinord, mostly in the 19th century (see Michie 1910). This landscape has seen surprisingly little archaeological investigation in recent years, despite its outstanding preservation (Stratigos \& Noble 2014). 


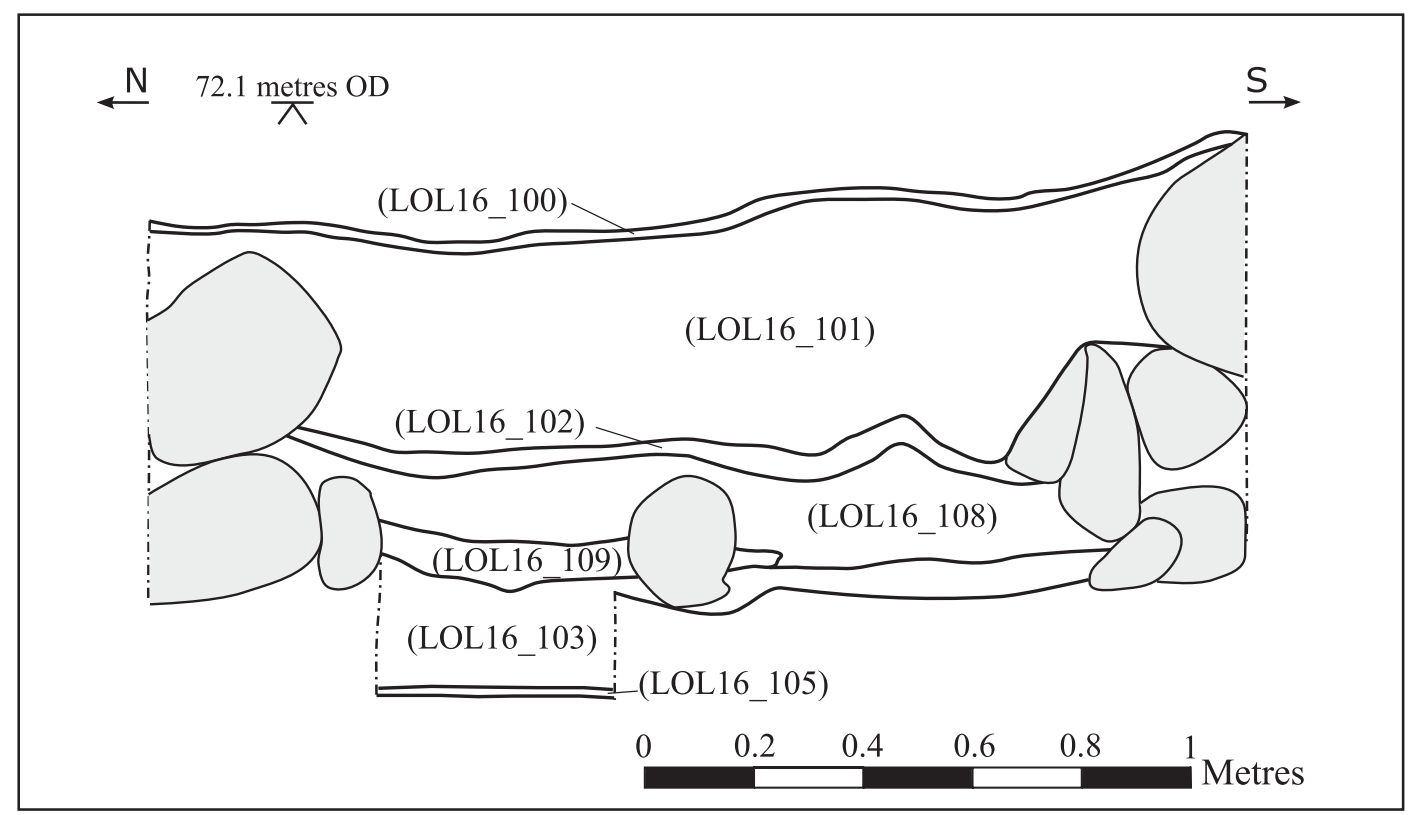

ILLUS 7 West-facing section of excavation trench at the Loch of Leys crannog

The former level of Loch Kinord is approximately $1 \mathrm{~m}$ higher than it is now (currently $c 161 \mathrm{~m}$ OD). The loch was lowered during a drought in 1836 and again in 1858 (Michie 1910: 88). Michie suggests the combined drop in the level of the loch was between 3 and $4 \mathrm{ft}(0.9$ $1.2 \mathrm{~m})$.

Castle Island is located $80 \mathrm{~m}$ from the north shore of Loch Kinord (Illus 8). Recorded as a castle from the 14th century to the 17 th century (Simpson 1943: 71; Stratigos \& Noble 2014: 213-14), the site measures approximately $100 \mathrm{~m} \times 80 \mathrm{~m}$ above the current level of the loch and about $120 \mathrm{~m} \times 100 \mathrm{~m}$ below the waterline. The island is ringed in trees with steep slopes that rise $c 3.5 \mathrm{~m}$ above the surface of the water to a flat central area that is sub-rectangular in shape, with a small annex on the east side of the island. The submerged portions of the island also rise sharply from depths between $2.5 \mathrm{~m}$ and $2 \mathrm{~m}$ below the surface of the water before levelling off at about $0.2-0.4 \mathrm{~m}$ below the surface of the loch. This area $0.2-0.4 \mathrm{~m}$ below the water ringing the island is covered in fine sediment overlying a mixed deposit of large rounded cobbles and smaller angular stones, with occasional large boulders around the current shoreline.

A fuller description of the previous finds made at Castle Island can be found in Stratigos \& Noble (2014: 210-14), but some key points are repeated here. The earliest accounts of Loch Kinord's archaeology come from the Old Statistical Account which records that between Castle Island and the north shore of Loch Kinord many timbers were pulled up, and the account and subsequent antiquarian investigations reference a timber causeway that came ashore roughly where the Kinord cross-slab now stands. Castle Island and Loch Kinord more generally appear to have been locally famous in the 18th and 19th centuries as a source for timber (Michie 1910: 82). The 2011 fieldwork obtained a sample from a submerged timber, possibly associated with the historically attested causeway, that returned a date of cal AD 880-1015 (SUERC-36812, 95.4\% probability) (Stratigos \& Noble 2014: 217).

A topographic survey of the island revealed a $7 \mathrm{~m}$ rise from the deepest area of natural loch bed to the flat central area of the island. The size of the island might suggest a natural origin, 
but underwater observation noted the striking similarity to other large artificial islands (eg Lochindorb Castle, Dixon 2004: 78 83). Timber features were identified across the western and northern side of the island, but none were found around the eastern side. The timbers noted included two which emerge from the mound of the island, suggesting that the island is at least partly artificial. The total extent of the island above water would have been noticeably smaller in the past due to the higher level of the water, comprising an area of 0.44 ha, compared to 0.60 ha currently. The central flat area of island measures 0.13 ha. The steepness of the slopes up to the central flat area is suggestive of scarping or artificial construction. The earthwork is comparable in scale to that of motte castles (see below). The excavation results presented below show that there has been substantial erosion which has reduced the incline of the slope of the island as it stands today (Illus 10).

Five trenches were opened across the islet, but three opened in the interior of the island revealed

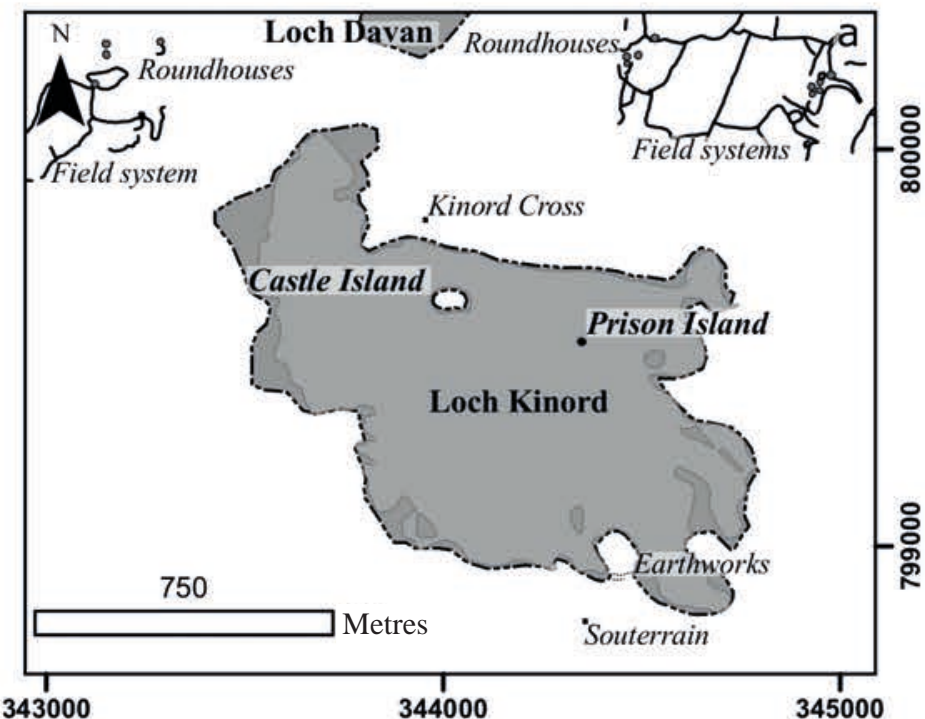

ILLus 8 (a) Location of Castle Island in relation to the former (dark grey with dashed outline) and current (lighter grey) extent of Loch Kinord; (b) aerial photograph of Castle Island looking north

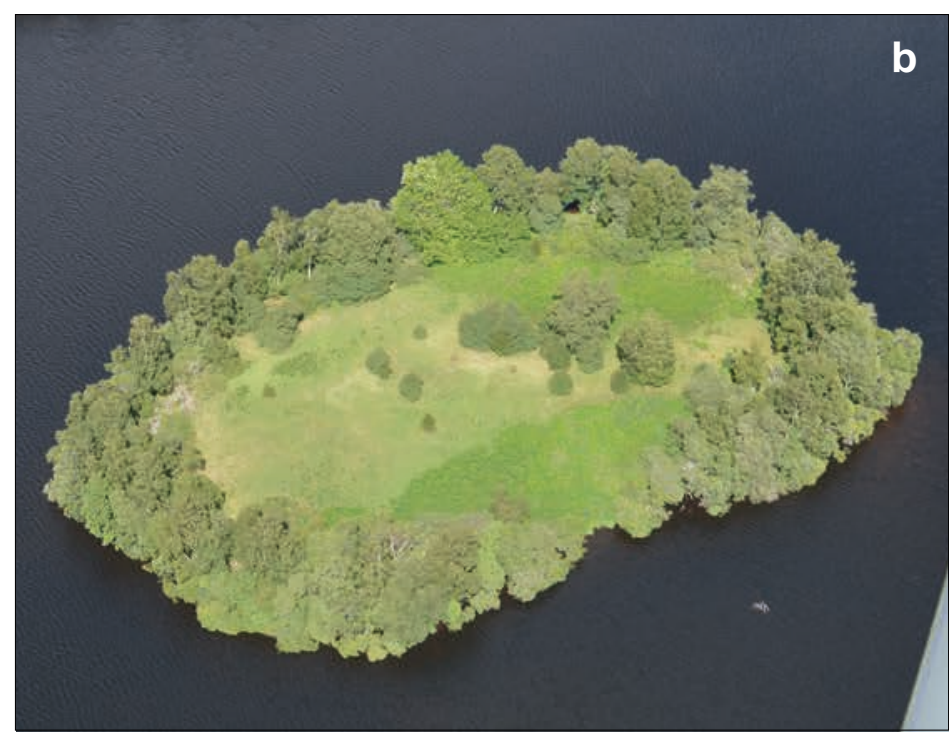
only topsoil sitting above redeposited natural material characterised by spreads of varying depths of cobbles, gravels and sands. The evidence for this being redeposited rather than strictly natural comes from the stratigraphy described below, and the fact that the deposits changed dramatically in character in plan within the relatively small trenches (eg
Contexts (CI15_402/407/409/410) were all variable in character, composed of sands, gravels and cobbles) (Illus 9b).

Trench 1 was $1 \mathrm{~m} \times 1 \mathrm{~m}$, located at the base of the slope on the west side of Castle Island. The trench revealed topsoil (CI15_104) and colluvium with charcoal inclusions (CI15_102) 


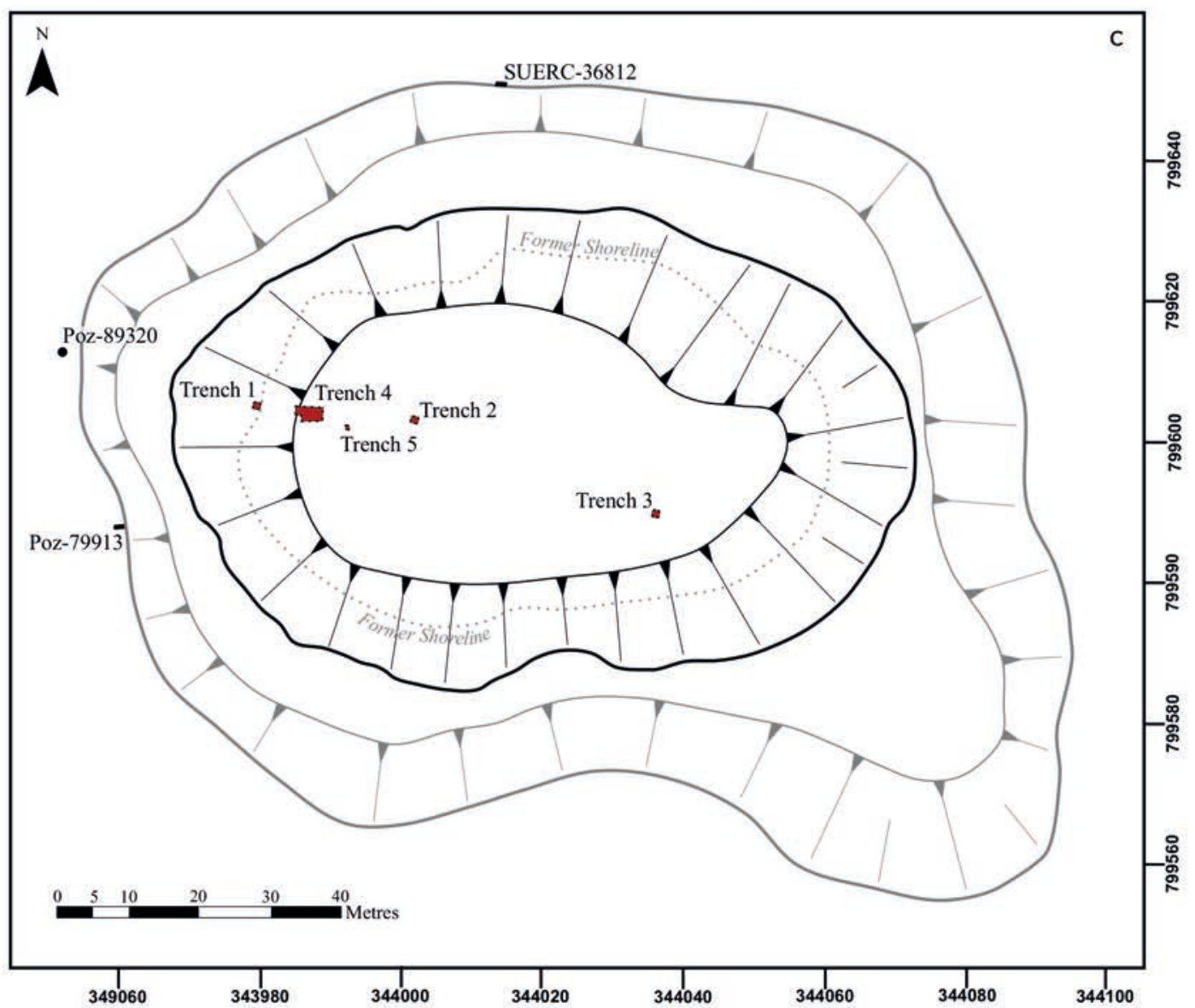

ILLus 8 (c) Survey of Castle Island and location of the excavation trenches with dated submerged timber features labelled by ${ }^{14} \mathrm{C}$ lab code

above an orange sand (CI15_103) which likely represents naturally deposited lacustrine material from near the former waterline (Illus 9a). Under the sand was a charcoal rich sandy silt deposit (CI15_104), interpreted as a midden layer just below the former waterline at the edge of the occupied island.

Trench 4 was placed over the break of slope from the flat central area of the island. It was $2 \mathrm{~m} \times 3 \mathrm{~m}$ with a $1 \mathrm{~m} \times 1 \mathrm{~m}$ extension on the west side. The trench revealed evidence for substantial cut features, such as a large pit [CI15_417], which was filled by (CI15_103) and post-hole alignments or a palisade trench (CI15_404/405/408/411/412) which ran nearly parallel to a spread of stones
(CI15_406) (Illus 9). From (CI15_404) a fragment of ceramic, most likely a crucible, was also recovered. A possible post-hole [CI15_413] and palisade trench [CI15_414] were identified below redeposited sands. The post-holes and palisade trenches appear to relate to a structure enclosing the central flat area of the island (Illus 9).

From Contexts (CI15_104) and (CI15_411), radiocarbon dates of cal AD 1020-1155 (Poz$79915,95.4 \%$ probability) and cal AD 1030-1185 (Poz-79914, 95.4\% probability) respectively were obtained (Table 1). These contexts most likely relate to the occupation of the medieval castle on Castle Island. A 10th-century AD date was recovered from a sample from a submerged 

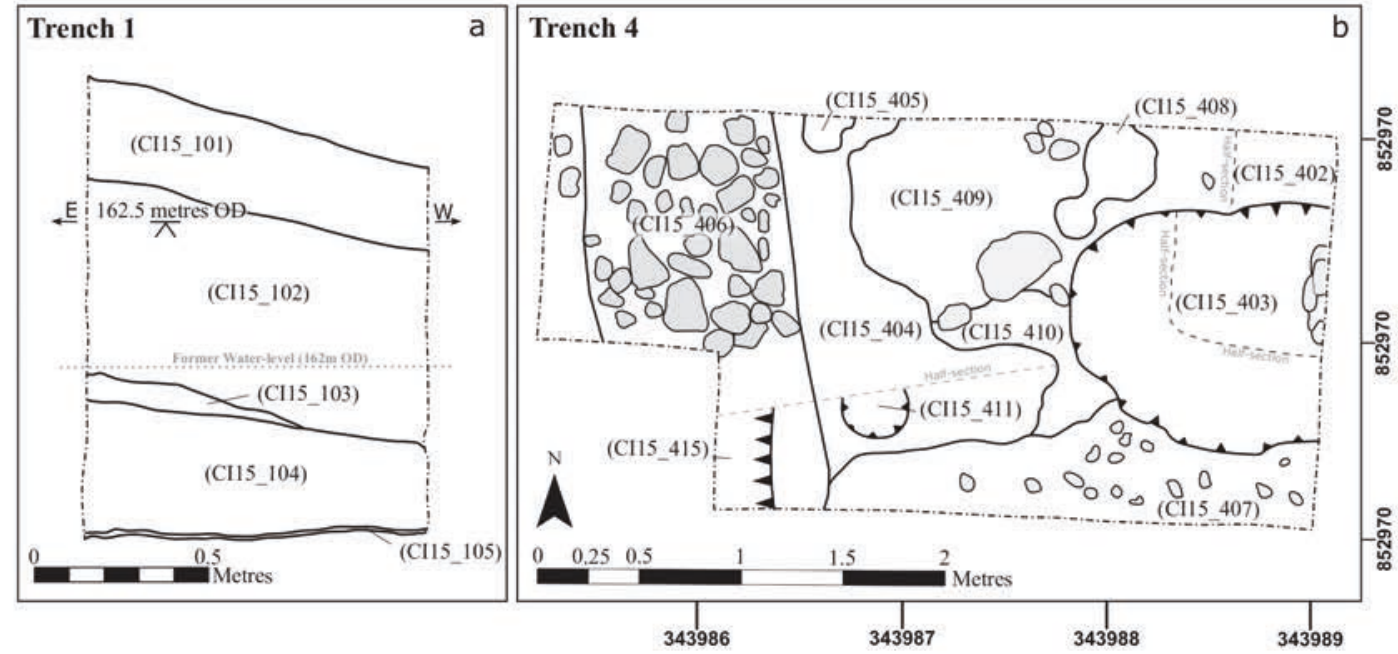

ILlus 9 (a) West-facing section of Trench 1 at Castle Island, showing the former level of the loch at $c$ 162m OD;

(b) Plan of Trench 4 at Castle Island, note that (CI15_403) fills Cut [CI15_417], (CI15_411) fills Cut

[CI15_412] and (CI15_415) fills the palisade trench [CI15_414]

timber, possibly relating to the historically attested causeway, at Castle Island in 2011 (Stratigos \& Noble 2014: 215). Allowing for potential old wood effect, the timber may be contemporary with the samples from the excavated contexts. Two further dates recovered from submerged timbers returned earlier dates. The first was from a large horizontal timber that was found embedded into the submerged slope of the island mound. This sample was oak heartwood, so some old wood effect must be allowed for, but it returned a date of 805-555 cal BC (Poz-79913, 95.4\% probability). The final date comes from an angled, likely oak, pile, $2 \mathrm{~m}$ from where the slope of the island hits the natural loch bed. This returned a date of cal $A D$ 585-665 (Poz-89320, 95.4\% probability) (Table $1)$.

Oak timbers (and heartwood in these cases) were sampled in the submerged work because that is what survives proud of the loch bed sediments. Oak sapwood and other wood species tend to survive only within a crannog mound or when covered completely by loch sediment. There is also the possibility that old wood was recycled, in particular reuse of Early Iron Age wood within medieval structures. However, the most likely source of such recycled timber would be an earlier crannog site. Furthermore, it is clear that there was an available oak timber resource here in the medieval period, evidenced by the submerged timber dated to the 10th century AD.

\section{PRISON ISLAND, LOCH KINORD, ABERDEENSHIRE}

Prison Island, 300m from Castle Island, is a near circular crannog mound and measures $15 \mathrm{~m} \times 19 \mathrm{~m}$ above the waterline and $40 \mathrm{~m} \times 42 \mathrm{~m}$ below. The surface of the mound is a rocky matrix of stones no larger than $0.5 \mathrm{~m}$ across, and it stands a maximum of $1 \mathrm{~m}$ above the waterline (Illus 11). Below water, the mound is covered in fine lake silt, with several timber features identifiable.

Previous investigation of Prison Island has been limited to survey in 2011 and minor antiquarian notes about the foundations of the islet (Stratigos \& Noble 2014). Michie (1910: 94) recorded some details regarding the timber features he identified from the surface, but his interpretation was largely speculative. The 2011 survey identified timber features across the submerged crannog mound and sampled a vertical pile just off the mound for ${ }^{14} \mathrm{C}$ dating. 


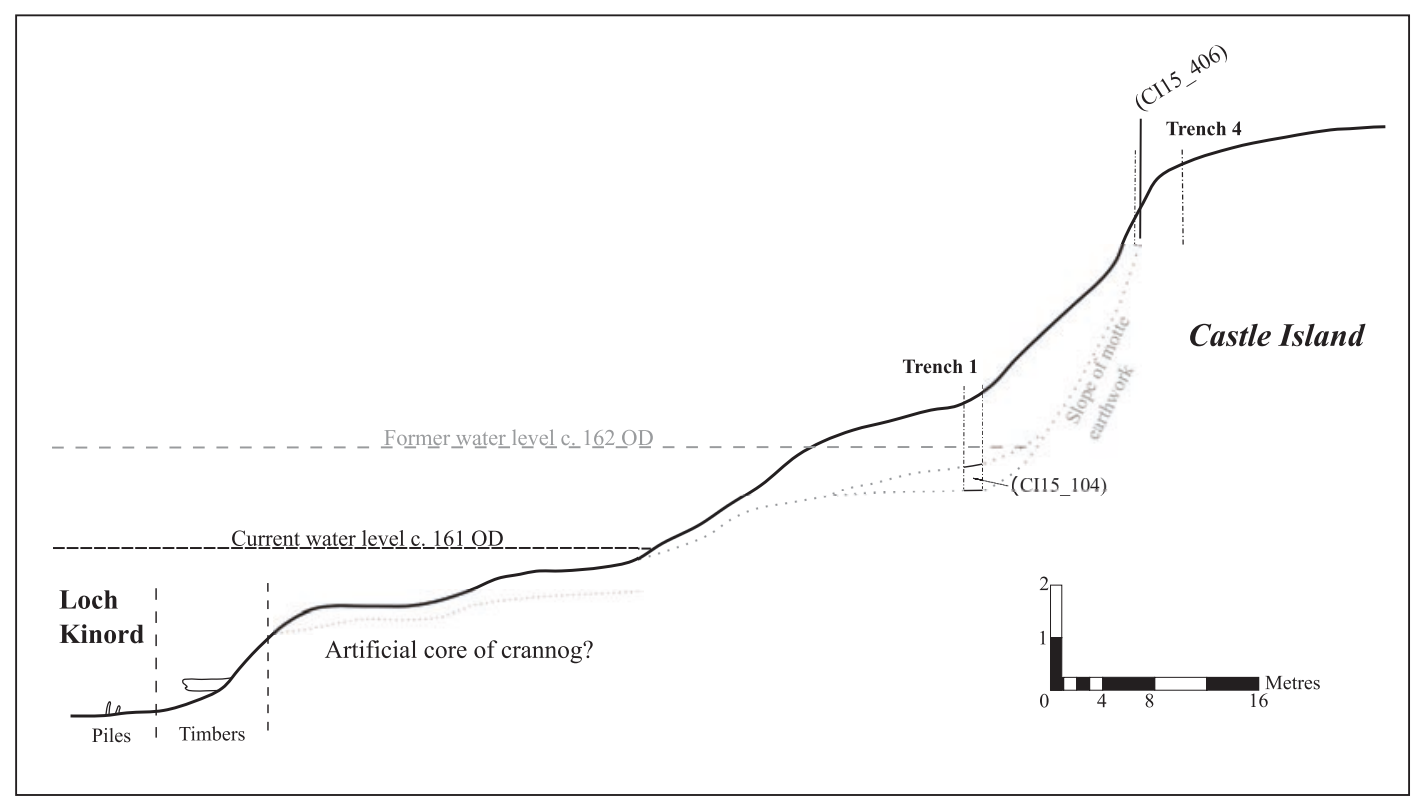

ILLus 10 Schematic profile of Castle Island (with a factor of four vertical exaggeration). Note, the piles and timbers are not drawn to scale

That sample returned a date of cal AD 720-940 (SUERC-36811, 95.4\% probability) (Stratigos \& Noble 2014: 217).

Above water, the crannog is a gently and evenly sloping rocky mound with a $3 \mathrm{~m} \times 1 \mathrm{~m}$ depression to the south-east side of the mound that may be the remains of a boat naust. There are no other features above water on the crannog. Below water, the presence of submerged fallen trees made close inspection of some areas of the crannog mound difficult or impossible. Underwater, all of the timber remains identified in the 2011 survey were relocated and only one new feature was identified - a timber emerging horizontally from the south side of the mound (Illus 11). The timber extended $0.6 \mathrm{~m}$ from the mound and had a diameter of between 0.1 and $0.15 \mathrm{~m}$. As this timber was firmly embedded within the crannog mound it was sampled for ${ }^{14} \mathrm{C}$ dating. It may represent a horizontal structural timber of the crannog platform or a later extension of the platform. The submerged radial timber identified returned a date of cal $\mathrm{AD}$ 1025-1170 (Poz-72879, 95.4\% probability). All of the identified submerged timber features were located on the southern and western sides of the islet.

A $1 \mathrm{~m} \times 1 \mathrm{~m}$ trial trench revealed that the above water portion of the crannog had lost all of its organic matrix, and is composed solely of stones no greater than $0.5 \mathrm{~m}$ diameter with the voids filled with peat (PI15_101). Water was encountered at $0.7 \mathrm{~m}$ below the surface of the crannog and at this interface over the whole $1 \mathrm{~m} \times 1 \mathrm{~m}$ trench, a layer of waterlogged and carbonised wood fragments were found within the voids between the rocks (PI15_102). This layer continued further, but the trench was terminated due to ingress of water. A small fragment of charred roundwood (Corylus cf avellana) from the waterlogged layer was selected and returned a radiocarbon date of cal AD 780-1015 (Poz79916, 95.4\% probability) (Table 1).

\section{DISCUSSION}

The new fieldwork on crannogs in north-east Scotland has revealed possible new sites and improved our understanding of the existing dataset. Beginning with the Houff, the excavated 
stratigraphy demonstrates that the mound is of artificial construction and sits within the former extent of Loch Auchlossan - on balance, we can suggest the site is most likely a crannog given its landscape location and the character of the excavated evidence. The discovery of a new crannog is encouraging for the future positive identification of crannogs in drained contexts (Stratigos 2016b, 2017). Work in Ireland has recently confirmed the presence of a previously unknown crannog in a drained setting through geophysical methods (Conyers 2018: 75-90), which offers another methodology to employ in searching for crannogs in the well-drained landscapes of north-east Scotland. The main body of the Houff is an anthropogenic organic sediment, akin to the 'dark earths' found at urban sites where there is rapid accumulation of organic structural and domestic detritus (see Heimdahl (2005) for discussion of 'dark earth'). The radiocarbon date from the Houff is relatively late and this might call into question its reclassification as a crannog; however, construction of crannogs is

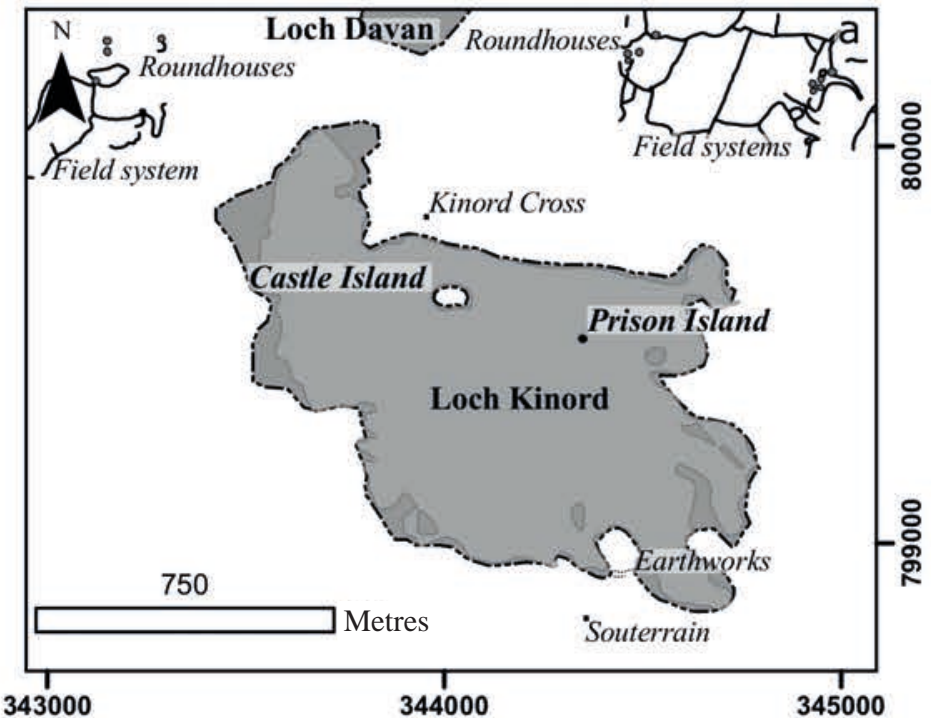

ILLus 11 (a) Location of Prison Island in relation to the former (dark grey with dashed outline) and current (lighter grey) extent of Loch Kinord;

(b) aerial photograph of Prison Island looking north

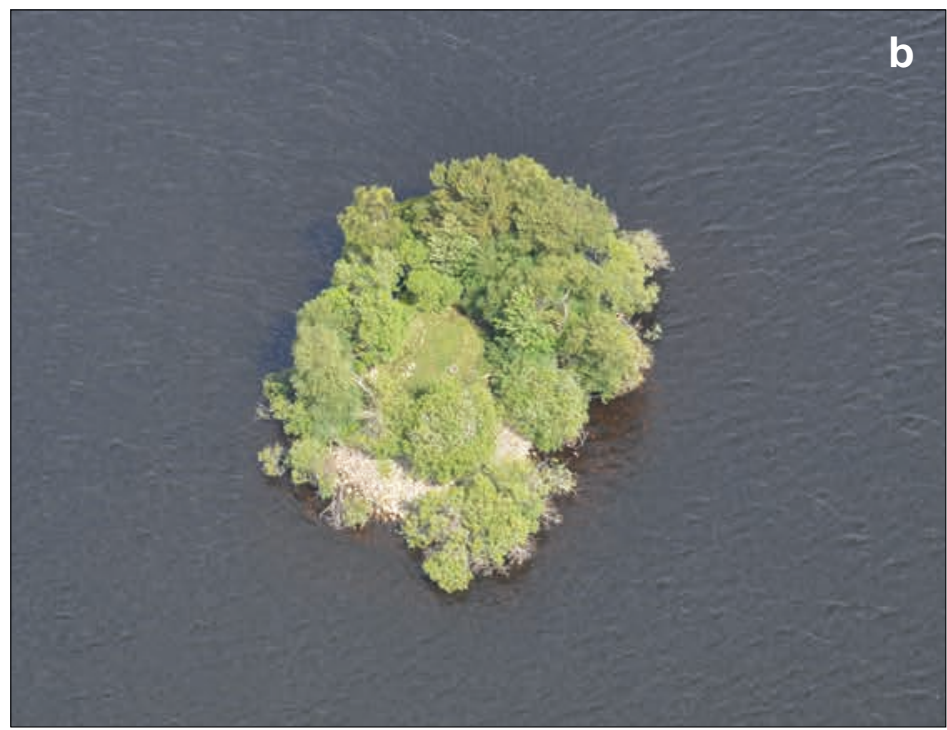
not unknown in a 15 th-16th century context (eg Keppoch's Council Isle, Loch Treig (Crone \& Cavers 2010)). Furthermore, there is no reason to rule out an earlier initial phase of construction at the Houff, as programmes of dating on crannogs have shown that stratigraphy on these sites can be inverted from what might be expected, especially at the edge of the crannog mound where smaller-scale excavation is usually undertaken (Cavers \& Henderson 2005: 296-7). The 16th-century radiocarbon date is broadly contemporary with recorded use of the Houff as a burial ground, and it is possible that the site was used at this time alongside reoccupation of the Peel of Lumphanan and Auchenhove Castle, both 


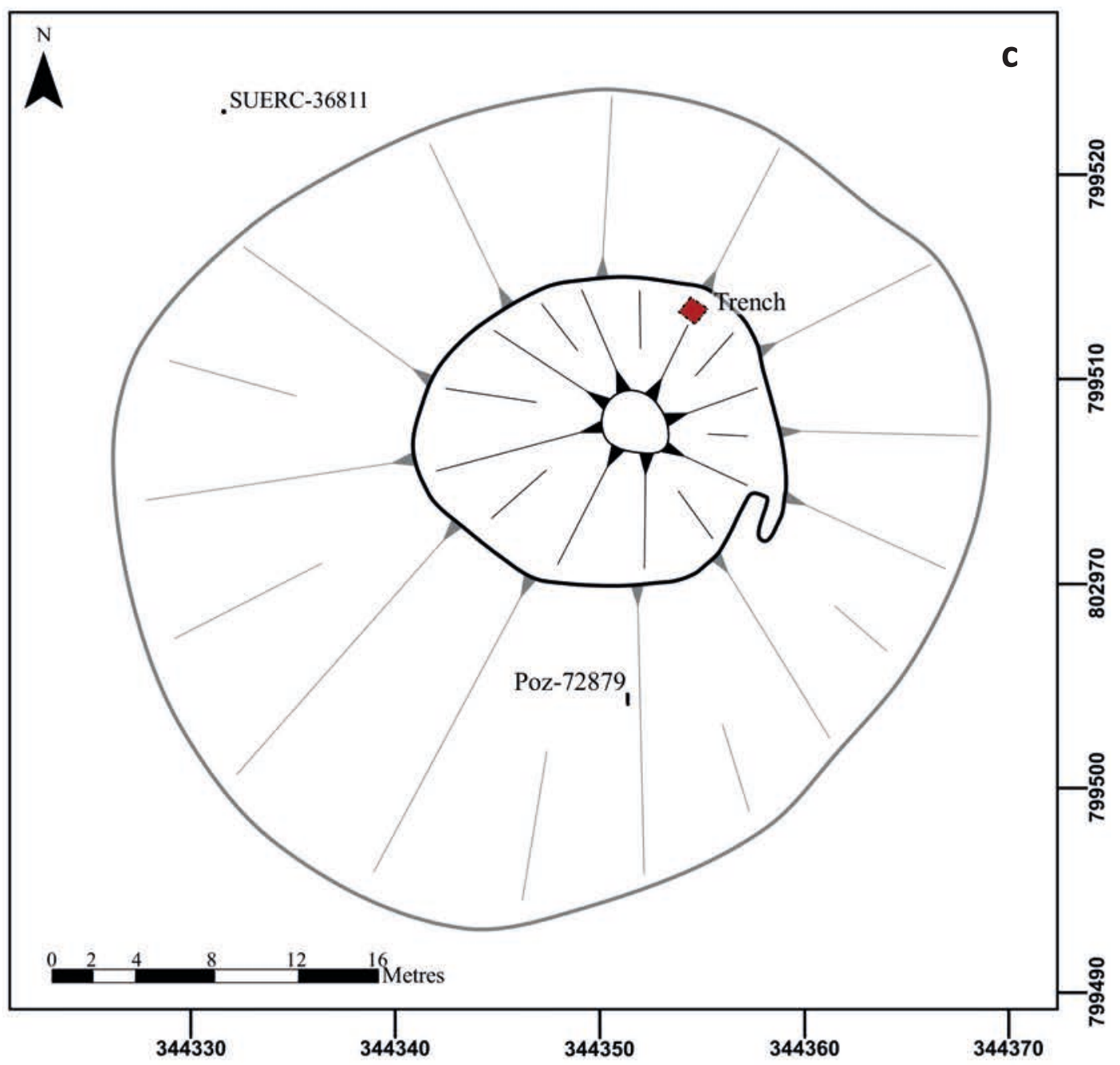

ILlus 11 (c) Survey of Prison Island and location of the excavation trench with dated submerged timber features labelled by ${ }^{14} \mathrm{C}$ lab code

of which were in use around this period (Simpson 1929: 23; Newton \& Talbot 1998: 669).

At the Loch of the Clans I, the excavation revealed that the preservation of the crannog is relatively poor. The timber and organic material of the crannog mound (Grigor 1864) has decayed once again, to a 'dark earth' over the 200 years following drainage. The Loch of the Clans crannog sits somewhere between the Houff and the Loch of Leys crannog in terms of preservation, and this can be directly related to the relative levels of saturation of these sites ( $\mathrm{cf}$
Chapman \& Cheetham 2002). The survey and excavation also revealed that the site is modest in terms of size and Grigor's excavations truncated much of the depth of the crannog mound. The radiocarbon evidence produced from the Loch of the Clans crannog is notable as one of just a few examples of a crannog which has ${ }^{14} \mathrm{C}$ evidence for occupation in the 1 st or 2 nd century $\mathrm{AD}$ (Jacobsson et al 2017: 16). Loch of the Clans I is also unusual for seemingly representing a crannog with only a single phase of use - although the excavation was not extensive enough to posit this 
with full confidence, but the smaller size relative to many other crannogs might suggest a single or limited number of phases of occupation. There is little evidence for settlement around the Loch of the Clans contemporary with the radiocarbon dates returned from the site, however, potentially contemporary settlement in the area might be represented by the cropmarks of a roundhouse (NH85SW 11), a ring-ditched house (NH85SW 36), as well as possible crannogs in Loch Flemington and Lochan Dinty (Grigor 1864: 118-19).

Excavation of the Loch of Leys has again shown how drainage has impacted crannogs in north-east Scotland. One hundred and sixty-five years after the loch was drained, the organic elements of this crannog have almost entirely decayed. However, the surviving remains are in better condition than at the Houff or the Loch of the Clans I. While the poor preservation of these three sites is disappointing, there is potential in pursuing further these decayed mounds with other techniques - such as soil micromorphological analysis - that might extract more information in terms of the kinds of activities, phasing and wider environment that characterised settlement at these well-drained crannog sites. The radiocarbon dates from the Loch of Leys crannog have indicated phases of use in the Roman Iron Age and early medieval periods. This is the most easterly crannog dated so far in Scotland and is thus notable that it shows evidence for use in the Iron Age. Some scepticism could apply to the security of the Iron Age date, given its secondary context, but on balance, it seems likely that the material was redeposited from an earlier phase of the crannog. The likely 10th-century $\mathrm{AD}$ date from the Loch of Leys crannog adds to the growing dataset suggesting relatively widespread occupation of crannogs in eastern Scotland in the late 1st millennium AD. The survival of well-laid stonework capping the organic matrix of the crannog mound could represent a move away from timber as the main building material sometime after the 9th-10th century AD.

Castle Island is the largest site investigated in the present campaign of fieldwork. The contexts uncovered in the excavations allow for two potential interpretations of the nature of Castle
Island. Although the submerged survey suggests a mostly artificial construction, the excavation on top of the mound revealed naturally derived deposits into which negative features were cut. The two possible models here are: the medieval phases augmented a natural island which saw previous augmentation in the Early Iron Age and 1st millennium $\mathrm{AD}$, or the island is mostly or completely artificial with an Early Iron Age crannog reoccupied in the 1 st millennium $A D$, which saw in the 11th-12th century massive redeposition of natural material on top of a series of earlier crannog occupations. Given the presence of timbers emerging from the island underwater, a mostly or wholly artificial interpretation of the remains at Castle Island is favoured (Illus 10), but only further excavation, including underwater survey and/or coring of the main body of the crannog would be able to resolve the true nature of the site.

The early phases at Castle Island have not yet been characterised since evidence for them comes from exposed timber elements and their associated contexts have not been excavated. Nonetheless, it can be suggested that the crannog was initially constructed in the Early Iron Age, first built as a completely artificial island or as an augmented natural island. The Early Iron Age radiocarbon date from Castle Island is the earliest so far from a crannog in northeast Scotland. The Early Iron Age origin for Castle Island is particularly important, dating the crannog building tradition in north-east Scotland to the Early Iron Age 'crannog eventhorizon' identified by Cavers (2006: 402). With the mid-1st-millennium AD radiocarbon result from the pile, Castle Island now parallels a large number of other crannog sites in having Iron Age origins followed by early medieval phases of construction and activity (eg Ederline Boat House (NM80SE 18), Loch Awe, Cavers \& Henderson 2005; Eilean nam Breaban (NN63NW 3), Loch Tay; Dixon et al 2007: 677; inter alia). Further evidence for activity on Loch Kinord during the early medieval period is attested to by dating of the 'Royal Yacht' logboat recovered from Loch Kinord in 1858, which was dated as part of this research to cal AD 555-650 (Poz-71094, 95.4\% probability) (Table 2). The later dates from 
Castle Island fall in the 11th-12th centuries when a major reoccupation and remodelling of the site occurred. At this time, a large earthwork motte was erected over an existing crannog/augmented island and a mostly timber structure was put in place around the top of the mound, encircling an area of approximately 0.13ha. Further use of Castle Island in this period is evidenced by a paddle found in the loch which was ${ }^{14} \mathrm{C}$ dated to the 11th-12th centuries (SUERC-42238) (Stratigos \& Noble 2014: 217) (Table 2). From this point, the site is documented historically, featuring in the nearby Battle of Culblean in 1335, and used as royal stop-over for King James IV in 1505, before being razed by Act of Parliament in 1648 (Simpson 1929: 130-1).

Fieldwork at Prison Island allows us to propose a direct relationship between the two crannogs in Loch Kinord. There now appears to be at least two phases of construction at Prison Island, one in the 8th-9th centuries AD followed by further construction activity in the 11 th-12th centuries. This latter addition is broadly contemporary with one phase of Castle Island. The degree to which occupation of Prison Island was continuous through this time remains open for speculation, and it would repay further investigation. The radiocarbon evidence gathered from this latest fieldwork strengthens arguments put forward in Stratigos and Noble (2014: 217-19) that Castle and Prison Islands, as a contemporary pair, formed a significant lordly residence(s) from the late 1st millennium AD onwards. An important parallel for the contemporary use and possible function of the two Kinord crannogs are the crannog Eilean na Comhairle (NR36NE 20) and natural islet Eilean Mor (NR36NE 5), in Loch Finlaggan, Islay. Loch Finlaggan is historically documented as the centre of power for the 'Lordship of the Isles', with Eilean na Comhairle recorded as the 'Council Island' upon which sat the meeting hall. Eilean Mor, around $40 \mathrm{~m}$ away, was where the main residence along with other attendant buildings were located (Caldwell \& Ewart 1993). Eilean na Comhairle has a radiocarbon date that suggests a construction or occupation event in the late 5th to mid-7th century AD, not long before the earliest date from Prison Island (Caldwell 2010: 49). It is possible

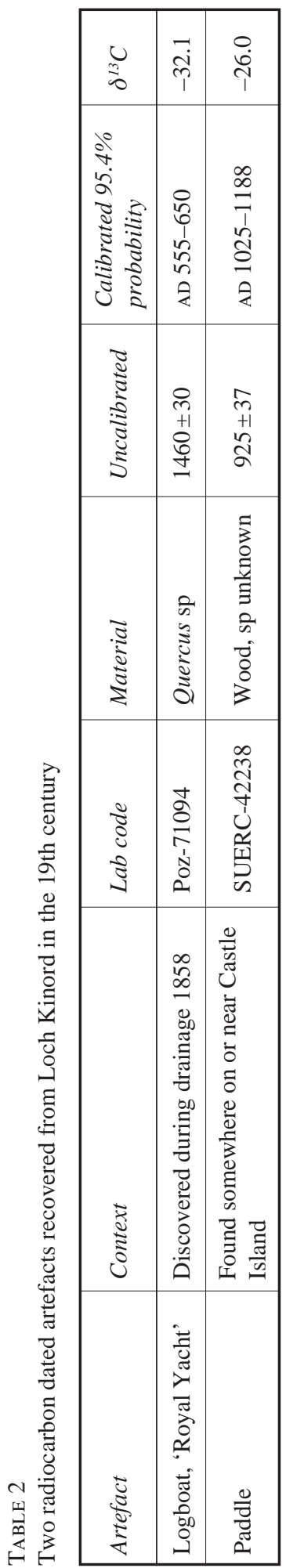


that Castle and Prison Islands were used in similar ways on Loch Kinord, one island acting as a residence and the other acting as a special location for the exercise of power in the Kinord area. Such functions may be related to their later place-names, one suggesting a residence (Castle Island), the other the exercise of lordly authority (Prison Island, formerly known as the 'Tolbooth', OSA, vol 12: 225), although this will, of course, remain speculative without larger programmes of excavation.

The later evidence from Castle Island suggests that the site might be viewed as cognate to an earth and timber motte castle, but in this case built and occupied as an island as opposed to a moated site. It is, for example, similar in size (by area) to the motte at Doune of Invernochty (NJ31SE 1), also located in the earldom of Mar Motte castles have been linked to incoming nobility to Scotland in the 12th century, as Scotland emerged as a feudal medieval nationstate (Davies 1990; Tabraham 1997; Oram 2008, 2011). Simpson (1919: 40) speculates that Castle Island may have been part of a group of castles that aimed to control the Mounth crossing through Mar from the 12th century onwards. The dating presented here might support this potential interpretation, but it would be among the earliest directly dated motte castles in Scotland. While Castle Island can be compared to a motte, it is also the case that it was built on a location with an existing history of islet dwelling. Oram (2008: 179) has suggested islet settlement might have been an expression of a local, Gaelic, identity among elites in the medieval period as a way to distinguish themselves from incoming Norman or Flemish nobility. This might contrast with motte castles that utilised and augmented natural features (cf RCAHMS 2007: 150-61). At Loch Kinord in the 11th-12th century we can also identify the continuation of the more classic crannog architectural tradition at Prison Island, perhaps further strengthening the argument that the intention of selecting an islet location for this castle was to make a connection to the tradition of crannog dwelling. Such direct engagement with what, even at that time, would be an ancient form of habitation, probably retaining cultural or social significance, might suggest local identities and power relationships that were carefully crafted around a vernacular tradition rather than imposed without regard for existing local cultural landscapes (cf Oram 2008, 2011). Further work at sites such as Castle Island would help explore these ideas further.

\section{CONCLUSIONS}

The fieldwork described here has resulted in evidence for crannogs in north-east Scotland dating from the Iron Age onwards, similar to other regions across Scotland (Cavers 2006: 402). We now also have a series of early medieval dates from crannogs in north-east Scotland, with the growing evidence for crannog use in the 9th10th centuries AD particularly notable, a period previously identified as one with little evidence for the use or construction of crannogs (Crone 2012: 149). In the north-east of Scotland we now have 9 th-11th century dates from Prison Island, Castle Island and Loch of Leys. These dates can be added to Edinample crannog (NN52SE 3), Loch Earn, Perthshire (Dixon 2007: 264), and a recently dated pre-castle crannog at Lochore, Fife (O'Grady 2017: 80-1) (Illus 12). Crannog research to date has rarely focused on sites with significant medieval occupation (ScARF 2012: 57), with the exception of Matthew Shelley's work (Shelley 2009, 2011, 2013). These new dates add vital evidence to suggest islet-dwelling was an important dimension of displaying and exercising lordship from the late 1 st millennium $\mathrm{AD}$ into the later medieval period. In a high medieval context, crannogs continued as lordly residences and their use included roles as hunting lodges, strategic fortifications or as highly visible habitations for a peripatetic aristocracy and/or religious elite (Shelley 2009: 40-5). The late 1stmillennium $\mathrm{AD}$ dates are also important given that they fill a lacuna in settlement evidence from this region and period when fortified settlements began to be abandoned or no longer saw episodes of construction (Noble et al 2013). These Castle Island, Prison Island, Loch of Leys, Edinample and Lochore dates represent important evidence for settlements in use between $c \mathrm{AD} 800$ and 1100 . 


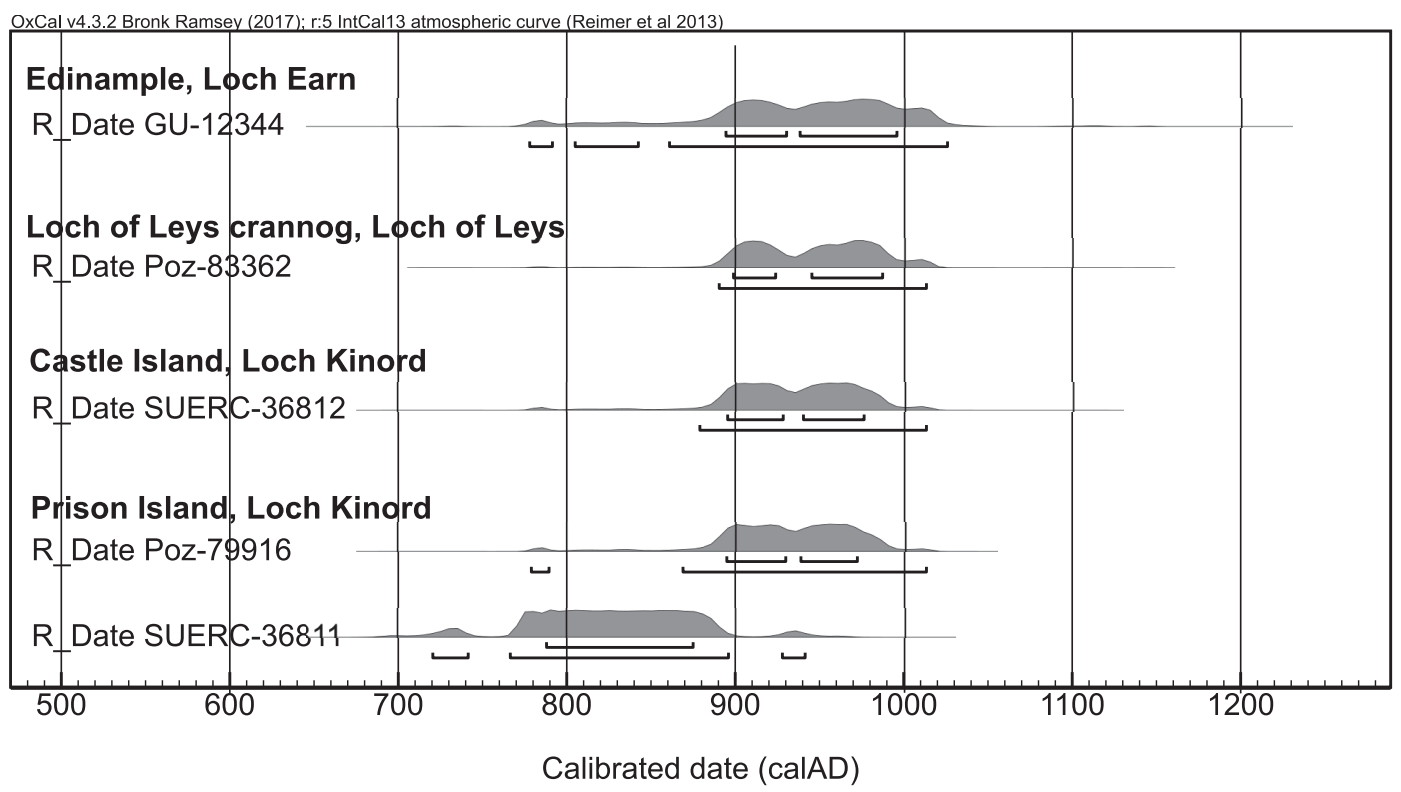

ILLus 12 Crannogs with radiocarbon dates that calibrate over the 9th-10th centuries AD. Note that Lochore Castle also has a radiocarbon date that calibrates over the 10th and 11th centuries AD, see O'Grady 2017

The Castle Island excavation shows us one way that the transition from crannog to medieval castle may have taken place. Here, massive reworking of the site took place that included the addition of substantial earthworks and a ringwork defence sometime in the 11 th-12th centuries. This might provide a model for other large medieval islet sites, some of which have shown evidence for being artificial islets, for example Lochindorb Castle (Dixon 2004: 78-83). At the Loch of Leys crannog, there is the suggestion that stone replaced timber construction sometime after the late 1st millennium $\mathrm{AD}$, but the exact timing of this shift remains unclear. Evidence for the relationship between the castellated architecture and the earlier crannog below sites such as Castle Island and the Loch of Leys is also an important area for future work. Such work would shed light on crannogs where early medieval occupation continued into the later medieval period and involved reworking of earlier sites and a change in the materials and styles of buildings that topped these islets.

Overall, the work presented here has established an initial regional chronology for crannogs in north-east Scotland. This chronology demonstrates that crannogs in north-east Scotland date from the Early Iron Age onwards, and that there is significant and growing evidence for crannog occupation in the early to high medieval periods. This is a significant step forward in our understanding of the crannogs of this region which until now have been overlooked or explained as later adoptions of an Atlantic Iron Age building tradition (Henderson 2009: 42; Cavers 2010: 268; Lenfert 2013: 133). The work presented here also helps show how gaps in the dating of sites across the country (eg a lacuna of dates in the 9th11th century AD, Crone 2012: 149) or regional distributions (eg few sites in eastern Scotland, Henderson 1998: 241) can be addressed through targeted fieldwork. At a broad scale, the artificial island dwelling phenomenon increasingly appears to be Scotland-wide, beginning in the Early Iron Age and continuing until the late medieval/early modern period. In terms of developing wider narratives for crannogs, it has been argued that we need more extensive dating programmes across a range of sites (Dixon et al 2007: 683), or more detailed work on fewer sites (Crone 2012: 164-5), 
but undoubtedly the most productive way forward here is to combine both approaches. Without continuing to examine regions where crannogs have been under-studied (that will necessarily begin with minimally invasive initial work), we cannot assess ideas about the timing and nature of the adoption of the crannog building tradition across Scotland. Similarly, without building more robust site-based chronologies that require extensive and well-contextualised samples, our understanding of crannogs will remain incomplete and remain unable to identify broader social and architectural change or contribute to wider narratives that assess the longue-durée of crannog occupation.

\section{ACKNOWLEDGEMENTS}

We kindly thank the Society of Antiquaries of Scotland, the Aberdeen Humanities Fund, the University of Aberdeen Findlay Harris Dick Prize for Pictish Research and the Archaeology Service for Aberdeenshire, Aberdeen City, Angus and Moray for providing funding for the work carried out. The authors would also like to the thank the landowners who granted permission for this work to be carried out, but in particular we would like to thank Catriona Reid and Thys Simpson for their help in facilitating access to sites. Thanks to NTS curators Vikki Duncan and Lauren Jackson for their help with the Loch of Leys bronze artefacts. Thank you to Bruce Mann for his support throughout this project. Thank you also to Susan Ramsay and Anne Crone who have assessed samples from these sites. Thanks also go to the large number of volunteers who have helped dive, survey and excavate over the past four years. And thanks to the three reviewers whose helpful comments have improved this paper. All errors remain our own.

\section{REFERENCES}

Bailey, E 2000 'The Crannog of Leys', in Bailey, E (ed.) Crannog to Castle, 225-31. Banchory: Leys Publishing.

Barber, J W \& Crone, A 1993 'Crannogs; a diminishing resource? A survey of the crannogs of south-west Scotland and excavations at Buiston Crannog', Antiquity 67: 520-33.
Blundell, O 1909 'Notice of the Examination, by means of a Diving-dress, of the Artificial Island, or Crannog, of Eilean Muireach, in the South End of Loch Ness', Proc Soc Antiq Scot 43: 159-64.

Burnett, J 1851 'Two Bronze Cooking Vessels in the Loch of Leys', Proc Soc Antiq Scot 1: 26-7.

Caldwell, D H 2010 'Finlaggan, Islay, the centre of the Lordship of the Isles. Excavations and fieldwork 1989-1998. Part two, introduction and background'. National Museums of Scotland Monograph Project Report. http:// repository.nms.ac.uk/id/eprint/214. Accessed 3 April 2018.

Caldwell, D H \& Ewart, G 1993 'Finlaggan and the lordship of the Isles: an archaeological approach', The Scottish Historical Review 72: 146-66.

Cavers, G 2006 'Late Bronze and Iron Age Lake Settlement in Scotland and Ireland: the development of the "crannog" in the north and west', Oxford Journal of Archaeology 25: 389-412.

Cavers, G 2007 'The complexity of crannog taphonomy: old and new evidence', in Barber, J, Clarke, C, Cressey, M, Crone, A, Hale, A, Henderson, J, Housley, R, Sands, R \& Sheridan, $\mathrm{J}$ A (eds) Archaeology from the Wetlands: Recent Perspectives. Proceedings of the 11th WARP Conference, Edinburgh, 2005, 243-53. Edinburgh: Society of Antiquaries of Scotland.

Cavers, G 2010 Crannogs and Later Prehistoric Settlement in Western Scotland. Oxford: British Archaeological Reports, British Series, 510.

Cavers, G \& Henderson, J 2005 'Underwater Excavation at Ederline Crannog, Loch Awe, Argyll, Scotland', International Journal of Nautical Archaeology 34: 282-98.

Cavers, G, Crone, B A, Engl, R, Fouracre, L, Hunter, F, Robertson, J \& Thoms, J 2011 'Refining Chronological Resolution in Iron Age Scotland: Excavations at Dorman's Island Crannog, Dumfries and Galloway', Journal of Wetland Archaeology 10: 71-108. https://doi. org/10.1179/jwa.2011.10.1.71.

Chapman, H P \& Cheetham, J L 2002 'Monitoring and modelling saturation as a proxy indicator 
for in situ preservation in wetlands - a GISbased approach', Journal of Archaeological Science 29: 277-89.

Conyers, L 2018 Ground-penetrating Radar and Magnetometry for Buried Landscape Analysis. Cham: Springer.

Crone, A 2007 "“From indirections find directions out"; taphonomic problems at Loch Glashan crannog, Argyll', in Barber, J, Clarke, C, Cressey, M, Crone, A, Hale, A, Henderson, J, Housley, R, Sands, R \& Sheridan, J A (eds) Archaeology from the Wetlands: Recent Perspectives. Proceedings of the 11th WARP Conference, Edinburgh, 2005, 223-30. Edinburgh: Society of Antiquaries of Scotland.

Crone, A 2012 'Forging a chronological framework for Scottish crannogs; the radiocarbon and dendrochronological evidence', in Midgley, M S \& Sanders, J (eds) Lake Dwellings after Robert Munro: Proceedings from the Munro International Seminar: The Lake Dwellings of Europe 22nd and 23rd October 2010, Edinburgh, 139-62. Leiden: Sidestone Press.

Crone, A 2014 'Dendrochronological Studies of Alder (Alnus glutinosa) on Scottish Crannogs', Journal of Wetland Archaeology 14: 22-33.

Crone, A \& Campbell, E 2005 A Crannog of the First Millennium AD: Excavations by Jack Scott at Loch Glashan, Argyll, 1960. Edinburgh: Society of Antiquaries of Scotland.

Crone, A \& Cavers, G 2010 'Eadarloch Crannog, Loch Treig, Lochaber. Technical report, publication report and survey', AOC Archaeology Ltd report to Historic Scotland. http://her.highland.gov.uk/Source/SHG26592. Accessed 3 July 2018.

Davies, R R 1990 Domination and Conquest: the experience of Ireland, Scotland and Wales, 1100-1300. Cambridge: Cambridge University Press.

Dixon, N 1981 'Preliminary excavation of Oakbank crannog, Loch Tay: interim report', International Journal of Nautical Archaeology 10: $15-21$.

Dixon, N 2004 The Crannogs of Scotland: An Underwater Archaeology. Stroud: Tempus Publishing Ltd.

Dixon, N 2007 'Crannog Structure and Dating in Perthshire', in Barber, J, Clarke, C, Cressey, M,
Crone, A, Hale, A, Henderson, J, Housley, R, Sands, R \& Sheridan, J A (eds) Archaeology from the Wetlands: Recent Perspectives. Proceedings of the 11th WARP Conference, Edinburgh, 2005. 253-65. Edinburgh: Society of Antiquaries of Scotland.

Dixon, N, Cook, G T, Andrian, B, Garety, L S, Russell, N \& Menard, T 2007 'Radiocarbon Dating of the Crannogs of Loch Tay, Perthshire (Scotland)', Radiocarbon 49: 673-84. https:// doi.org/10.1017/s0033822200042569.

Grigor, J 1863 'Notice of the Remains of Two Ancient Lake Dwellings or Crannoges, in the Loch of the Clans, on the Estate of James Rose, of Kilravock, Nairnshire, with a Plan', Proc Soc Antiq Scot 5(1): 116-19.

Grigor, J 1864 'Further Explorations of the Ancient Lake Dwellings in the Loch of the Clans, on the Estate of Kilravock, Nairnshire', Proc Soc Antiq Scot 5(2): 332-5.

Groome, F 1884 Ordnance Gazetteer of Scotland, A Survey of Scottish Topography, Statistical, Biographical, and Historical. Edinburgh: Thomas C Jack.

Harding, D W 2000 'Crannogs and Island Duns: Classification, Dating and Function', Oxford Journal of Archaeology 19(3): 301-17. https:// doi.org/10.1111/1468-0092.00111.

Heimdahl, J 2005 'Urbanised Nature in the Past: Site Formation and Environmental Development in Two Swedish Towns, AD 1200-1800', PhD thesis, Stockholm University. http://su.diva-portal.org/smash/ record.jsf?pid=diva2\%3A197550\&dswid $=$. Accessed 2 July 2018.

Henderson, J 1998 'Islets through time: the definition, dating and distribution of Scottish crannogs', Oxford Journal of Archaeology 17: 227-44. https://doi.org/10.1111/14680092.00060 .

Henderson, J 2009 'Taking the waters: Scottish crannogs and the Atlantic Iron Age', in Cooney, G, Becker, K, Coles, J, Ryan, M \& Sievers, S (eds) Relics of Old Decency: Archaeological Studies in Later Prehistory 39-48. Dublin: Wordwell.

Henderson, J, Cavers, G \& Crone, A 2006 'The south-west crannog survey: recent work on the lake dwellings of Dumfries and Galloway', 
Transactions of the Dumfriesshire and Galloway Natural History and Antiquarian Society 80: 29-51.

Jacobsson, P 2015 'Improving the ${ }^{14} \mathrm{C}$ dating of south-west Scottish wetland sites', $\mathrm{PhD}$ thesis, University of Glasgow. https://theses.gla. ac.uk/id/eprint/7231. Accessed 2 July 2018.

Jacobsson, P, Hale, A G C, Cook, G \& Hamilton, D 2017 'Exploring Site Formation and Building Local Contexts through Wiggle-Match Radiocarbon Dating: Re-Dating of the Firth of Clyde Crannogs, Scotland', European Journal of Archaeology. https://doi.org/10.1017/eaa. 2017.60.

Lenfert, R 2012 'Long-term continuity and change within Hebridean and mainland Scottish island dwellings', $\mathrm{PhD}$ thesis, University of Nottingham. https://eprints.nottingham.ac.uk/ id/eprint/13829. Accessed 2 July 2018.

Lenfert, R 2013 'Integrating Crannogs and Hebridean Island Duns: Placing Scottish Island Dwellings Into Context', The Journal of Island and Coastal Archaeology 8: 122 43. https://doi.org/10.1080/15564894.2013. 766912.

McArdle, C M, McArdle, T D \& Morrison, I 1973 'Notes: Scottish Lake-dwelling Survey: archaeology and geomorphology in Loch Awe, Argyllshire', International Journal of Nautical Archaeology 2(2): 381-2.

Michie, J G 1910 [2010] Loch Kinnord: Its History and Antiquities. Ballater: Deeside Books.

Morrison, I 1985 Landscape With Lake Dwellings: the crannogs of Scotland. Edinburgh: Edinburgh University Press.

Mowat, R 1996. The Logboats of Scotland. Oxford: Oxbow Books.

Munro, R 1882 Ancient Scottish Lake Dwellings or Crannogs. Edinburgh: Thomas \& Archibald Constable.

Munro, R 1893 'Notice of Crannogs or Lake Dwellings recently discovered in Argyllshire', Proc Soc Antiq Scot 27: 205-22.

[NSA] New Statistical Account. The Society for the Sons and Daughters of the Clergy (eds) 1845. The New Statistical Account of Scotland. Edinburgh.
Newton, N \& Talbot, E 1998 'Excavations at the Peel of Lumphanan, Aberdeenshire, 1975-9', Proc Soc Antiq Scot 128: 653-70.

Noble, G, Gondek, M, Campbell, E \& Cook, M 2013 'Between prehistory and history: the archaeological detection of social change among the Picts', Antiquity 87: 1136-50. https://doi.org/10.1017/s0003598x00049917.

O'Grady, O J T 2017 'Lochore Castle - discover the ancient Lomonds, watching brief', Discovery and Excavation in Scotland, New Series 17: 80-1.

Oram, R 2008 'Royal and Lordly Residence in Scotland $c 1050$ to $c$ 1250: an historiographical review and critical revision', The Antiquaries Journal 88: 165-89. https://doi.org/10.1017/ s0003581500001372.

Oram, R 2011 Domination and Lordship: Scotland, 1070-1230. Edinburgh: Edinburgh University Press.

[OSA] Old Statistical Account. Sinclair, J (ed.) 1791-9. The Statistical Account of Scotland. Edinburgh.

Piggot, M 1953 'Milton Loch Crannog I. A native house of the 2nd century $\mathrm{AD}$ in Kirkcudbrightshire', Proc Soc Antiq Scot 87: 134-52.

RCAHMS 2007 In the Shadow of Bennachie; A Field Archaeology of Donside, Aberdeenshire. Edinburgh: Society of Antiquaries of Scotland.

Reimer, P J, Bard, E, Bayliss, A, Beck, J W, Blackwell, P G, Bronk Ramsey, C, Grootes, P M, Guilderson, T P, Haflidason, H, Hajdas, I, Hatt, C, Heaton, T J, Hoffmann, D L, Hogg, A G, Hughen, K A, Kaiser, K F, Kromer, B, Manning, S W, Niu, M, Reimer, R W, Richards, D A, Scott, E M, Southon, J R, Staff, R A, Turney, C S M \& van der Plicht, J 2013 'IntCal13 and Marine13 Radiocarbon Age Calibration Curves 0-50,000 Years cal BP', Radiocarbon 55: 1869-87.

Ritchie, J 1942 'The lake-dwelling, or crannog in Eadarloch, Loch Treig: its traditions and its construction', Proc Soc Antiq Scot 76: 8-78.

Roy, W 2007 The Great Map: The Military Survey of Scotland 1747-55. Edinburgh: Birlinn. 
ScARF 2012 Atkinson, D \& Hale, A (eds) Marine and Maritime Panel Report. Scottish Archaeological Research Framework: Society of Antiquaries of Scotland. http://tinyurl.com/ c5d7txv. Accessed 2 July 2018.

Shelley, M 2009 'Freshwater Scottish loch settlements of the late medieval and early modern periods; with particular reference to northern Stirlingshire, central and northern Perthshire, northern Angus, Loch Awe and Loch Lomond', $\mathrm{PhD}$ thesis, University of Edinburgh. http://hdl.handle.net/1842/5806. Accessed 3 April 2018.

Shelley, M 2011 'Timothy Pont and the Freshwater Loch Settlements of Late Medieval and Early Modern Mainland Scotland', Scottish Geographical Journal 127: 108-16. https:// doi.org/10.1080/14702541.2011.586643.

Shelley, M 2013 'The Isle of Loch Clunie: the key to the see of Dunkeld', Innes Review 64: $39-65$.

Simpson, W D 1919 'The Doune of Invernochty', Proc Soc Antiq Scot 53: 34-45.

Simpson, W D 1929 'The Early Castles of Mar (First Paper)', Proc Soc Antiq Scot 63: 102-38.

Simpson, W D 1943 The Province of Mar. Aberdeen: Aberdeen University Press.

Stratigos, M J 2016a 'The lost lochs of Scotland: Tracking land-use change and its impact on the archaeological record', Journal of Wetland Archaeology 16: 1-19. https://doi.org /10.1080/14732971.2016.1248129.
Stratigos, M J 2016b 'A Reconsideration of the Distribution of Crannogs in Scotland', in Erskine, G J R, Jacobsson, $\mathrm{P}$, Miller, $\mathrm{P}$ \& Stetkiewicz, S (eds) Proceedings of the 17th Iron Age Research Student Symposium, Edinburgh 29th May-1st June 2014, 95-106. Oxford: Archaeopress.

Stratigos, M J 2017 'Crannogs in north-east Scotland: understanding the resource', $\mathrm{PhD}$ thesis, University of Aberdeen. http: //ethos.bl.uk/OrderDetails.do?uin=uk. bl.ethos.731628. Accessed 3 April 2018.

Stratigos, M J \& Noble, G 2014 'Crannogs, castles and lordly residences: new research and dating of crannogs in north-east Scotland', Proc Soc Antiq Scot 144: 205-22.

Stuart, J 1866 'Notice of a Group of Artificial Islands in the Loch of Dowalton, Wigtownshire and of other Artificial Islands or "Crannogs" throughout Scotland', Proc Soc Antiq Scot 6: 114-78.

Stuart, J 1874 'Note of Recent Excavations at St Margaret's Inch, in the Loch of Forfar', Proc Soc Antiq Scot 10: 31-4.

Sutherland, K 1989 'Auchenhove, Lumphanan Parish', Discovery and Excavation in Scotland 1989: 24.

Tabraham, C J 1997 Scotland's Castles. London: B T Batsford.

Yeoman, P 1988 'Mottes in Northeast Scotland', Scottish Archaeological Review 5: 125-33. 